\title{
Information exposure, perceptions and behaviours during the first COVID-19 wave in Germany: Evidence from survey and Facebook data
}

\author{
Sebastian Stier \\ Fabian Flöck
}

\author{
Bernd Weiß \\ Johannes Breuer \\ Mirjan Schulz
}

\author{
Timo Hartmann \\ Ines Schaurer
}

\section{7,990 words}

\begin{abstract}
The role of information exposure during the COVID-19 pandemic seems ambiguous, as gains in knowledge from public information campaigns stand against fears of widespread misinformation, especially via social media. Using data from a large survey collected during the first COVID-19 wave in March 2020 as well as data from Facebook, this paper investigates from which sources (e.g., public or commercial broadcasting, newspapers or Facebook) Germans received news and how information exposure relates to perceptions, attitudes and behaviours concerning COVID-19. Regression analyses based on the survey data show that getting COVID-19related information from a multitude of sources strongly predicted positive public health outcomes and that no individual source had negative effects. A quantitative text analysis of almost a million German public Facebook posts indicates that the positive individual-level effects might be related to a uniform coverage of COVID-19 that emphasised the severity of the pandemic, whereas misinformation seemed to be less widespread than feared. The results suggest that fears of an 'infodemic' may be overstated and that the high salience of COVID-19 in media coverage helped the efforts to mitigate the pandemic. We discuss the findings against the backdrop of an increased politicisation of public-health measures during later COVID19 waves.
\end{abstract}

Keywords: COVID-19, Information Exposure, Infodemic, Media, Facebook, Misinformation 


\section{Introduction}

Lacking a vaccine and treatments against COVID-19, non-pharmaceutical interventions such as national lockdowns or encouragement of social distancing measures were the only available instruments for governments to contain the pandemic during the first wave in Spring 2020 (Flaxman et al. 2020). Yet even during the height of the COVID-19 crisis, substantial shares of citizens in developed democracies did not comply with mandated counter-measures or at least did not fully embrace the severity of the pandemic. Policy makers like the World Health Organization (WHO) and public actors have talked about an 'infodemic', suspecting people's information exposure as a possible root cause for this negligence. Social media platforms such as Facebook were the prime suspects, as they allow content from non-expert users or unreliable sources to proliferate almost unchecked, independent of its trustworthiness or quality. However, it is still largely unclear how important social media are as a pathway to COVID-19 related information in general. Therefore, it is important to take a step back and assess citizens' news diets in their entirety. In this paper, we investigate the role of information exposure during the first COVID-19 wave in March 2020 in Germany by seeking answers to the following set of research questions:

RQ1 Which sources did German citizens use for getting information on COVID19 ?

RQ2 How are different types of information exposure associated with perceptions, attitudes and behaviours related to COVID-19?

RQ3 Were there differences in coverage of COVID-19 between information sources?

The study relies on two data sources. The first one is data from the GESIS Panel special survey on COVID-19, fielded from 17th to 29th March 2020, which utilises the online sample of the GESIS Panel (GESIS Panel Team 2020). This large panel study with more than 3,000 respondents represents the heterogeneity of the adult population in Germany. In addition to its sample size, this data source has the advantage of containing media exposure measures and a detailed breakdown of different outcomes related to COVID-19. As information exposure might have heterogeneous relations with different dimensions, we analysed four different dependent variables: risk perceptions, perceptions of government measures, the attitudinal dimension of trust in relevant policy actors and the behavioural dimension of personal measures to mitigate the pandemic. The second data source is Facebook which is the most widely (weekly used) social media platform in Germany (Beisch and Schäfer 2020). To substantiate differences in media coverage by different sources, we collected almost a million public Facebook posts and conducted a quantitative text analysis.

The findings show that traditional information sources were still the predominant channels from which citizens acquired COVID-19 related information, whereas social media platforms only played a minor role. Our multiple regression models reveal a strong positive association between the number of sources 
used and COVID-19 outcomes. One of the reasons for this positive relationship might be the almost uniform coverage across sources. Our quantitative text analysis of the posts by the most popular German Facebook pages shows that across information sources - even a heterogeneous set of political actors - similar medical and political dimensions related to COVID-19 were salient. In contrast, there was almost no evidence for any types of misinformation or doubts about the severity of the pandemic. The joint findings suggest that public information campaigns can help mitigate the COVID-19 pandemic. Yet we discuss in the conclusion that the political and information environment has changed considerably in the wake of an increasing politicisation of political countermeasures in later COVID-19 waves.

\section{COVID-19 and information exposure}

During the early stage of the COVID-19 pandemic in Spring 2020, the information environment was characterised by considerable uncertainty. Lacking clear and robust scientific evidence on the severity of the pandemic and the efficiency of measures taken against it by governments, questionable - or plainly wrong - information could not just be found on social media, but also in more established sources of information. In early February already, the WHO was actively engaging with social media platforms to tackle what it called the 'infodemic' related to COVID-19. ${ }^{1}$

There is a growing body of research on the supply side of information on COVID-19, either concentrating on coverage by established news organisations or user-generated content on social media. While research from the U.S. has shown that news coverage on the COVID-19 pandemic was highly politicised and polarised (Hart, Chinn, and Soroka 2020), evidence from Germany found no evidence of major systemic failings or strong biases in the Facebook messages of established news providers from January to March 2020 (Quandt et al. 2020). On the other hand, a similar content analysis looking at so-called 'alternative news media' revealed that COVID-19 was fed into the anti-systemic ideological frames these pages typically follow (Boberg et al. 2020). However, despite considerable public attention to online misinformation, it is still largely unclear how widespread exposure to such fringe contents actually is, not least due to limited insights into the types of content that are popular on Facebook.

Research on the demand side primarily investigated what types of COVID-19 information citizens are exposed to. In a ten-country survey from early March 2020, $70 \%$ of respondents reported getting COVID-19 information daily. At the same time, $74 \%$ of respondents worried about fake news about the pandemic and $45 \%$ indicated that they were struggling to find trustworthy information (Edelman 2020). Relatedly, 67\% of respondents in a Reuters Digital News Report survey in April 2020 reported having seen at least some misinformation regarding COVID-19 on social media (Newman et al. 2020). Nonetheless, most

\footnotetext{
${ }^{1}$ https://www.nytimes.com/2020/02/06/health/coronavirus-misinformation-socialmedia.html
} 
people still got COVID-19 information from major news organisations (Edelman 2020; Newman et al. 2020).

Some studies also focused on the relationship between information exposure and COVID-19 outcomes. Two quasi-experimental studies from the U.S. showed that exposure to the ambiguous coverage of Fox News during Spring 2020 reduced compliance with countermeasures (Ash et al. 2020; Simonov et al. 2020). A country-comparative study including Germany found that misinformation (information perceived as unintentionally wrong) and disinformation (information perceived as intentionally wrong) about the virus were perceived as prevalent in information environments. Perceptions of higher misinformation prevalence were related to more information seeking and more compliance with public health guidelines. In contrast, people who felt that they encountered intentionally wrong information were less likely to comply with mandated measures and were more likely to actively avoid COVID-19 information (Hameleers, van der Meer, and Brosius 2020). This was confirmed by Siebenhaar, Köther, and Alpers (2020) who found that German respondents who were distressed by information consequently avoided information on the pandemic and complied less with public health measures, and similarly, by Imhoff and Lamberty (2020) who revealed a lower compliance among people holding conspiracy beliefs about the virus.

While these findings suggest that, in principle, some information can be harmful in the fight against the pandemic, several studies also identified information exposure as a positive correlate of public-health compliant behaviours and attitudes. In a comparative study, citizens in six countries emphasised the gains in knowledge they acquired from news media coverage on the pandemic (Nielsen et al. 2020). Regression analyses confirmed that getting information from news organisations is associated with higher levels of factual knowledge about the virus. Importantly, relying on social media as an information source was not negatively associated with knowledge about COVID-19 (Nielsen et al. 2020). Rothmund et al. (2020) also showed that being exposed to public broadcasting news was the most important predictor of having knowledge about and evaluations of COVID-19 in line with scientific expert judgements.

More generally, beyond the context of the pandemic, there is no solid theoretical or empirical basis for expecting uniform negative effects of social media. Several analyses have shown that established media organisations still dominate the market for online news, whereas hyperpartisan or so-called 'fake' news providers only play marginal roles (Allen et al. 2020; Guess forthcoming; Guess, Nagler, and Tucker 2019; Stier et al. 2020b). Oftentimes, users even stumble upon news they do not actively seek out on Facebook or other social media platforms (Scharkow et al. 2020); a process commonly referred to as 'incidental news exposure'.

To investigate the relationship between exposure to various sources of information and COVID-19-related attitudes, perceptions and behaviours, this paper jointly takes into account the demand and supply side of information. We couple high-quality survey data from around 3,000 respondents that included questions about information exposure and COVID-19 outcomes with an analysis of public 
Facebook posts during the first wave of COVID-19 in March 2020 in Germany. Most closely related to our research is the paper by Siebenhaar, Köther, and Alpers (2020) who studied the relationship between information avoidance and compliance with preventive measures. While providing important insights into information behaviour and its individual-level consequences, their study differs from ours in four main points: (1) the convenience sample they recruited from social media platforms and the university website was skewed in several regards (e.g., almost $80 \%$ female respondents); (2) only one outcome variable was analysed: compliance with preventive measures; (3) information exposure was not used as a predictor, but only as an indirect measure of information avoidance; (4) there was no analysis of the actual content of news coverage on COVID-19.

When it comes to outcomes related to COVID-19, most related research has not systematically distinguished various relevant dimensions. For instance, information exposure might be positively associated with public health attitudes without necessarily having any relation with adhering to government measures to contain the pandemic. To arrive at a more nuanced understanding of the role of information exposure during the first wave of COVID-19, this paper distinguishes four different outcomes. The first two outcomes can be regarded as perceptions, more precisely (1) the perceived probability of risks associated with COVID-19 to oneself and others and (2) the perceived effectiveness of government measures. We also take into account (3) relevant attitudes by capturing trust in people and institutions that are politically and administratively responsible for dealing with the COVID-19 pandemic. Finally, given that nonpharmaceutical interventions were the only available means that could be taken in Spring 2020, absent effective vaccines or treatments against COVID-19 (Flaxman et al. 2020), it is especially important to also investigate (4) (self-reported) compliance with public health measures and associated changes of behaviours.

\section{Research design}

Our research design combines high-quality survey data from a large survey with Facebook data collected during the first wave of COVID-19 in March 2020 in Germany.

\section{Survey data}

Sample. For the survey-based analyses, we utilise data from the GESIS Panel, a probability-based mixed-mode access panel, which comprises about 5,000 active panellists aged $20+$ with a mean age of 54 years $(S D=14.5)$. Each wave of the panel is conducted in a self-administered mixed-mode design, i.e., as an online or paper-based survey (Bosnjak et al. 2018). The "GESIS Panel Special Survey on the Coronavirus SARS-CoV-2 Outbreak in Germany" (GESIS Panel Team 2020) was conducted in the early days of the pandemic in Germany, between 
March 17 and March 29, 2020. ${ }^{2}$ Since the survey had to be conducted in a timely manner, the survey was limited to the online subsample of the GESIS Panel. The special survey included a wide range of questions on perceptions, attitudes and behaviours regarding COVID-19 (see below).

Overall, $\mathrm{N}=3,765$ respondents were invited to participate, $\mathrm{N}=3,176$ of whom completed the survey, resulting in a completion rate of $84.36 \%$. For the analyses in this paper, the GESIS Panel Special Survey was linked to the cumulative GESIS Panel Standard Edition (GESIS 2020b) as well as the Extended Edition (GESIS 2020a). Due to item nonresponse for about $7 \%$ of cases, the final sample size is approximately $N \sim 2,940$, with slight differences across the four dependent variables.

Since respondents in the GESIS Panel were allowed to self-select into the respective survey modes for participating in the COVID-19 special survey (i.e., online- or paper-based surveys), the current sample cannot be considered a probability sample (for a discussion of selection bias in the context of COVID-19 online surveys, see Schaurer and Weiß 2020). Therefore, especially the descriptive results cannot be generalised to a broader population. A comparison of the sample with population margins can be found in the Online Appendix, Section 1.

The questionnaire of the GESIS Panel Special Survey is the result of joint work in the Open Probability-based Panel Association, ${ }^{3}$ the Department of Economics of the University of Bonn as well as the German Research Institute of the Federal Employment Agency. Experts in scale development and on substantive considerations based on current knowledge about how people react to pandemics guided the selection of items and scales (see also Rammstedt, Lechner, and Weiß 2021).

Dependent variables. First, risk perceptions were measured with five items asking about the likelihood that within the next two months, (a) respondents will get infected with COVID-19, (b) someone from their immediate social surroundings will get infected, (c) respondents will need hospital treatment because of an infection, (d) respondents will have to be quarantined, (e) respondents will get infected and spread the virus to other people. Response options for all of these items ranged from 1 - not likely at all to 7 - absolutely likely, with an additional option of indicating that this had already happened to them. The latter response category was treated as a missing value for the analysis of perceived risk. These items were combined into a single mean score (Cronbach's $\alpha=0.82$ ).

Second, respondents were asked how they perceive the effectiveness of seven different measures for containing the pandemic (e.g., closing kindergartens and schools or a curfew for at-risk populations), with response options ranging from 1 - not effective at all to 7 - very effective. The combined mean score has a

\footnotetext{
${ }^{2}$ The data from the "GESIS Panel Special Survey on the Coronavirus SARS-CoV-2 Outbreak in Germany" is available as a public use file (PUF), for more information see GESIS Panel Team (2020). In addition, the PUF has been included in the cumulative scientific use file of the GESIS Panel GESIS (2020b).

${ }^{3}$ https://openpanelalliance.org
} 
Cronbach's $\alpha$ of 0.87 .

Third, trust was assessed by asking participants how much they trusted nine different actors or institutions in dealing with the pandemic (e.g., the federal government, the $\mathrm{WHO}$, or scientists). Response options for these items ranged from 1 - don't trust at all to 5 - entirely trust. Cronbach's $\alpha$ for the mean scale is 0.89 .

Fourth, respondents where asked whether they engage in a set of ten different prevention behaviours (e.g., washing their hands more often, avoiding certain places, or reducing social contacts), with the option of also naming additional behaviours. These eleven binary items were combined into a single sum score. All four dependent variables were rescaled to a range of 0 to 100 to facilitate interpretation. The complete item wording and descriptive statistics of all variables can be found in Sections 2 and 3 of the Online Appendix.

Independent and control variables. The survey contained self-report items of media exposure asking respondents about their use of information sources for getting COVID-19 information. The items included the higherlevel, dichotomous categories public broadcasting and commercial broadcasting, both in their national and local/regional variants, national and local newspapers, Facebook, other social media and personal conversations. Respondents were asked to report usage independent of the channel where they received the information (online, offline, apps). While more detailed ways of measuring the intensity of media exposure (e.g., in usage days per week for each source), such as the list-frequency technique exist, the simpler list-technique usually performs equally well to assess the aggregate levels of exposure (Andersen, de Vreese, and Albæk 2016). As our research questions do not require detailed information at the source level (e.g., whether someone read the BILD Zeitung), the available measures serve our purposes well. For the regression models, we construct a variable COVID-19 information exposure as an additive index of used information sources, ranging from 0 to $10(\mathrm{M}=3.89, \mathrm{SD}=1.57)$.

In order to account for the role of respondents' political orientation, we include several control variables in the regression models, starting with political ideology (left-right) ranging from 0 - left to $10-\operatorname{right}(\mathrm{M}=4.65, \mathrm{SD}=1.87)$. Another relevant confounder is satisfaction with democracy with a scale of 0 - extremely dissatisfied to 10 - extremely satisfied $(\mathrm{M}=6.08, \mathrm{SD}=2.30)$. Additionally, respondents were asked about their current party choice ('Sonntagsfrage') if the federal elections were held next Sunday, with the following response categories: Alternative für Deutschland (AfD) (8\%), CDU/CSU (22\%), SPD (11\%), FDP (7\%), DIE LINKE (9\%), BÜNDNIS 90/DIE GRÜNEN (23\%), other party or don't know (21\%). ${ }^{4}$ Finally, we control for political interest, answered on a 5 -point scale ranging from 1 - not at all to 5 - very strong $(\mathrm{M}=$ $3.28, \mathrm{SD}=0.89)$.

The regression models also include sociodemographic variables. The distribution of females in the sample (49\%) corresponds roughly to that in the adult population in Germany (51\% female, see Statistisches Bundesamt 2020). Ed-

\footnotetext{
${ }^{4}$ This question was asked in an earlier wave of the GESIS panel in Spring 2019.
} 
ucation is operationalised based on the demographic standards of the Federal Statistical Office (Beckmann et al. 2016) and has been trichotomised into the categories 'low', 'medium' and 'high'. There is a pronounced over-representation of highly educated respondents (see Table A1 in the Online Appendix), i.e., $58 \%$ of the GESIS Panel respondents reported a 'high' educational attainment, whereas in the Microcensus 2017 this group has a share of about one third. However, the over-representation of highly educated respondents in our sample comes as no surprise, as it is in line with findings on the demographic composition of online surveys in general (Antoun 2015). Finally, household size is measured as a categorical variable with three categories (1 person, 2 persons, 3 and more persons). The proportion of single-person households is $11 \%$, twoperson households have a share of $48 \%$, and about $40 \%$ of the respondents live in a household with 3 or more persons.

\section{Facebook data and topic model}

Data. For the text analysis, we use Facebook as a data source which has several unique advantages for our study. Whereas transcripts of TV shows and texts of newspaper articles are not easily available for researchers, a large variety of content producers belonging to the information sources of interest publish content on Facebook. In addition, the consistent format allows for analysing and comparing the coverage of COVID-19 across information sources.

The data was retrieved from CrowdTangle, a data insights tool owned by Facebook that tracks the content of and interactions with public posts on Facebook pages (CrowdTangle Team 2020). ${ }^{5}$ Our data collection covers the period from December 1, 2019 to March 29 2020, which corresponds to the last day of the GESIS Panel Survey. Specifically, we retrieved all COVID-19-related posts issued during this period by German public Facebook pages. ${ }^{6}$ CrowdTangle was queried using a comprehensive query expansion strategy: Initially, we crawled all posts that included one of the terms corona or covid. Using these keywords, we gathered $\mathrm{N}=701,877$ unique posts made by public pages. We then applied the following regular expression (RegEx) to the posts' contents to filter out the most common COVID-19-related terms in a semi-inductive approach: corona.*|ncov.*| .*cov-2.*| covid.*|quarant.*|\#.*virus.*|\#.*bleib.*. ${ }^{7}$ From the list of the resulting terms, we removed corona and covid since they were already included in our initial query set. ${ }^{8}$ Next, we used the top 30 terms from the remaining list to query CrowdTangle again for the same period. ${ }^{9}$ Our

\footnotetext{
${ }^{5}$ CrowdTangle is accessible after a per-user authorisation given by Facebook to academic researchers, journalists and similar stakeholders. The tool does not provide insights into private user information, the identity of users or comments by individuals.

${ }^{6}$ CrowdTangle assigns pages to countries based on various pieces of information such as the location of page administrators and their popularity among users of a given country.

${ }^{7}$ Note that the query syntax of CrowdTangle does not allow to implement such RegEx commands natively. Hence we only apply them to the downloaded content.

${ }^{8}$ Additionally, we dropped all terms that contained either of the sub-strings bier, flasche, or brauerei to exclude contents referring to the Corona beer brand instead of COVID-19.

${ }^{9}$ coronavirus, \#corona, \#coronavirus, quarantäne, \#covid19, cov, coronakrise,
} 
final Facebook data set consists of $\mathrm{N}=855,516$ unique posts. 181,894 different public Facebook pages created at least one post related to COVID-19 in our data set.

Engagement is heavily skewed: the top 1,000 pages ranked by the number of interactions (the aggregated number of reactions, comments and shares) capture $58 \%$ of all interactions accumulated by the 181,894 public Facebook pages in our data. We therefore restricted our analysis to these top 1,000 pages, in order to then manually map them to the information source types present in the GESIS Panel Survey. Our sample of pages therefore captures the most popular, and by extension, the likely most seen public content on COVID-19 among German Facebook users. Since our substantial interest is in German posts and as a prerequisite for the effective application of our automated text analysis, we cleaned the data further. As the country-of-origin information for pages was imprecise to some extent, we also coded pages primarily posting in English and removed these. We then utilised Google's Compact Language Detector v3 $(\mathrm{CLD} 3)^{10}$ to identify and remove all remaining non-German posts.

Analysis. To gain a more structured view of the Facebook data, we applied a topic model to all posts made by the manually coded top pages. Concretely, we implemented a biterm topic model (BTM) (Yan et al. 2013), which is particularly suited to uncovering topics in short texts. To improve the relevant signals for our task, we further processed the raw contents according to the following steps: (1) converting letters into lower case; (2) removing emojis, URLs, digits, @-references, and the hashtag character (i.e., \#); (3) removing German stopwords; (4) removing all terms that matched the regular expression used during our query expansion; (5) removing terms with only one character; and (6) applying lemmatisation to each term. We utilized spaCy for stopword removal and lemmatisation (Honnibal et al. 2020). Finally, we removed all duplicate posts from the processed content. This left us with $\mathrm{N}=77,152$ valid posts and an average post length of 12.81 tokens, posted by 629 distinct Facebook pages. To find the optimal hyper-parameters for the BTM, we computed topic coherence scores

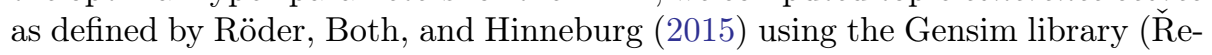
hưřrek and Sojka 2010). Overall, our tuning procedure comprised a total of 200 distinct parameter combinations. After optimising the model parameters based on coherence score, ${ }^{11}$ we arrived at 20 topics and the hyper-parameters $\alpha=4.1$ and $\beta=0.61$. We fitted the model with 500 iterations.

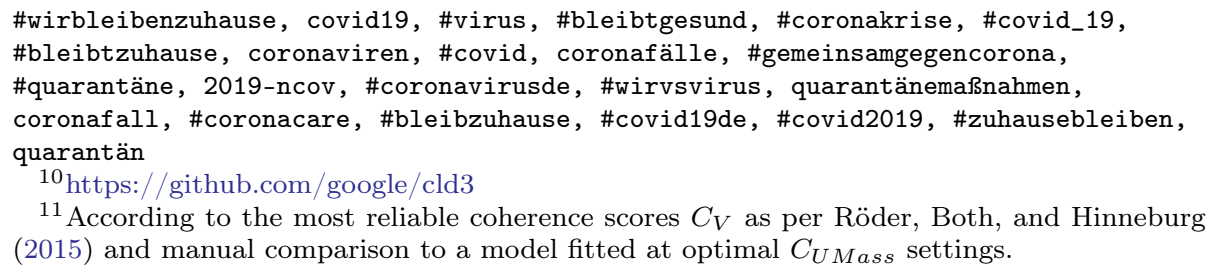

${ }^{11}$ According to the most reliable coherence scores $C_{V}$ as per Röder, Both, and Hinneburg (2015) and manual comparison to a model fitted at optimal $C_{U \text { Mass }}$ settings. 


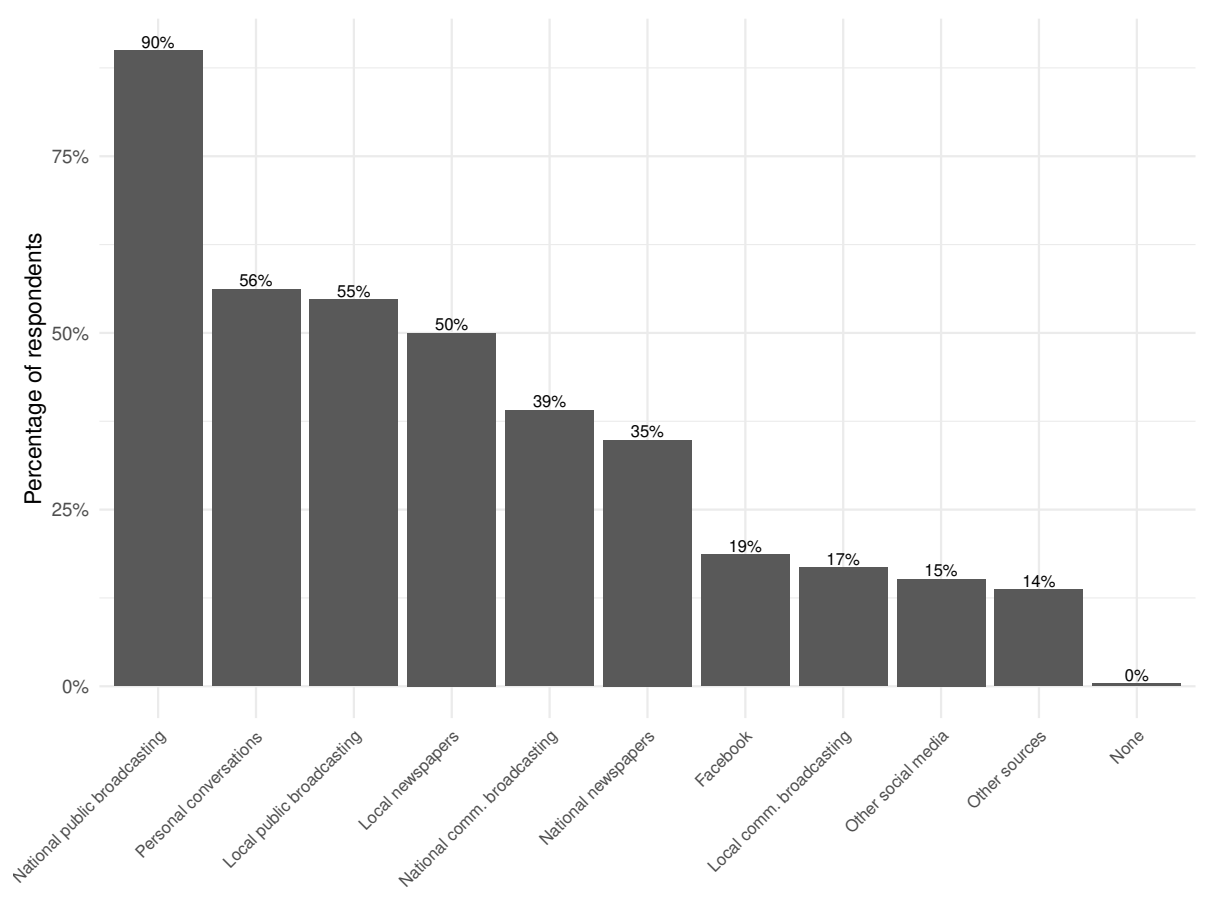

Figure 1: Information sources used for getting COVID-19 information.

\section{Results}

In the following, we will first present descriptive survey results on the sources of COVID-19 information. Next, we discuss results from regression analyses in which COVID-19 outcomes are regressed on information exposure, while controlling for relevant confounding variables. Finally, a quantitative text analysis is used to characterise differences and similarities in coverage of COVID-19 depending on the information source. Our analyses were performed in $R$, version 4.0.3 and Python, version 3.7. ${ }^{12}$

\section{Which sources were used for getting information on COVID- 19 ?}

Figure 1 displays the prevalence of sources used for getting information on COVID-19 (RQ1), independent of the distribution channel (e.g., online, on TV or in print versions). Public broadcasting radio or television, either national or local, were used by $92 \%$ of respondents. $67 \%$ of respondents got information from newspapers, when taking together local and national papers. $56 \%$ of re-

\footnotetext{
${ }^{12}$ Replication materials [anonymised for peer review] can be found on OSF: https://osf.io/4az8v/?view_only=d10894ad99e64da59ff71cc7bf46d716.
} 


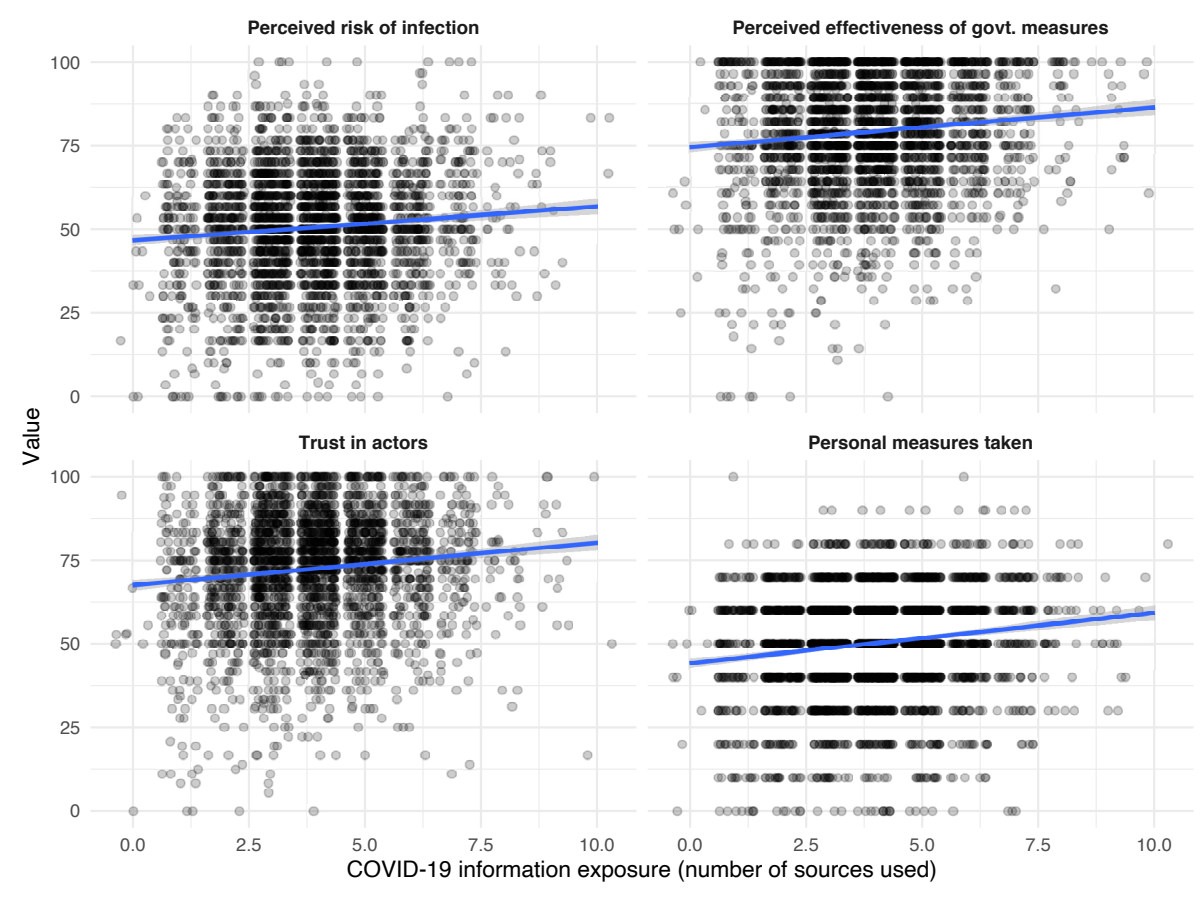

Figure 2: Bivariate relationships between media exposure and COVID-19 outcomes.

spondents also reported receiving information about COVID-19 from personal conversations and a total of $45 \%$ received such information from commercial broadcasters (national or local). Compared with these channels, social media were mentioned as far less frequent sources of COVID-19 information. Such exposure took place on Facebook among 19\% of respondents, while $15 \%$ got COVID-19 information on other social media. $14 \%$ reported additional sources, while only $0.3 \%$ of respondents reported not getting any COVID-19 information.

Taken together, the descriptive findings reveal an extraordinarily high salience of COVID-19 in the information diets of respondents and that established news sources were the predominant information providers. While the content analysis presented below will provide a more detailed picture of coverage on COVID-19, this makes clear that most respondents were exposed to substantial amounts of mainstream media coverage on the pandemic.

\section{How did information exposure relate to COVID-19 out- comes?}

We investigated RQ2 by first plotting the bivariate relationship of information exposure and COVID-19 outcomes. Figure 2 shows that being exposed to in- 
formation about the pandemic from more sources was associated with higher risk perceptions, perceived effectiveness of measures to contain the pandemic, trust in policy actors, and more personal measures taken to protect oneself and others. ${ }^{13}$ Yet additional political variables and individual characteristics could confound the bivariate relationships. Therefore, we next test these patterns in multiple regressions.

Table 1: Information exposure and COVID-19 outcomes.

\begin{tabular}{|c|c|c|c|c|}
\hline & \multicolumn{2}{|c|}{ Perceptions } & \multirow{2}{*}{$\frac{\text { Attitudes }}{\text { Trust in actors }}$} & \multirow{2}{*}{$\begin{array}{c}\text { Behaviours } \\
\text { Measures taken }\end{array}$} \\
\hline & Risk of infection & Effectiv. of measures & & \\
\hline \multirow[t]{2}{*}{ COVID-19 information exposure } & $1.17^{* * *}$ & $1.03^{* * *}$ & $0.87^{* * *}$ & $1.35^{* * *}$ \\
\hline & $(0.20)$ & $(0.20)$ & $(0.18)$ & $(0.18)$ \\
\hline \multirow[t]{2}{*}{ Political ideology (left/right) } & -0.06 & -0.03 & $-0.51^{* *}$ & 0.04 \\
\hline & $(0.20)$ & $(0.20)$ & $(0.19)$ & $(0.19)$ \\
\hline \multirow[t]{2}{*}{ Political interest } & $0.84^{*}$ & 0.26 & 0.14 & 0.73 \\
\hline & $(0.40)$ & $(0.40)$ & $(0.38)$ & $(0.37)$ \\
\hline \multirow[t]{2}{*}{ Satisfaction with democracy } & 0.28 & $0.67^{* * *}$ & $2.31^{* * *}$ & $0.50^{* * *}$ \\
\hline & $(0.15)$ & $(0.15)$ & $(0.14)$ & $(0.14)$ \\
\hline \multirow[t]{2}{*}{$\mathrm{CDU} / \mathrm{CSU}$} & -1.50 & 1.11 & $9.38^{* * *}$ & -1.00 \\
\hline & $(1.40)$ & $(1.39)$ & $(1.31)$ & $(1.31)$ \\
\hline \multirow[t]{2}{*}{ FDP } & -1.98 & -1.47 & $5.68^{* * *}$ & -1.41 \\
\hline & $(1.64)$ & $(1.62)$ & $(1.53)$ & $(1.52)$ \\
\hline \multirow[t]{2}{*}{ Grüne } & -0.43 & 0.50 & $6.68^{* * *}$ & -0.60 \\
\hline & $(1.50)$ & $(1.49)$ & $(1.40)$ & $(1.40)$ \\
\hline \multirow[t]{2}{*}{ Linke } & -3.07 & $-3.64^{*}$ & $3.38^{*}$ & $-4.74^{* *}$ \\
\hline & $(1.73)$ & $(1.71)$ & $(1.61)$ & $(1.61)$ \\
\hline \multirow[t]{2}{*}{ SPD } & -1.89 & -0.73 & $8.28^{* * *}$ & $-3.43^{*}$ \\
\hline & $(1.60)$ & $(1.58)$ & $(1.49)$ & $(1.49)$ \\
\hline \multirow[t]{2}{*}{ Other party or don't know } & -0.94 & -1.97 & $4.62^{* * *}$ & $-3.06^{*}$ \\
\hline & $(1.37)$ & $(1.36)$ & $(1.28)$ & $(1.27)$ \\
\hline \multirow[t]{2}{*}{ Household: 2 persons } & 1.18 & 1.59 & -1.02 & $2.12^{*}$ \\
\hline & $(1.01)$ & $(1.00)$ & $(0.95)$ & $(0.94)$ \\
\hline \multirow[t]{2}{*}{ Household: $3+$ persons } & $2.32^{*}$ & 2.04 & -1.51 & $4.85^{* * *}$ \\
\hline & $(1.06)$ & $(1.05)$ & $(0.99)$ & $(0.99)$ \\
\hline \multirow[t]{2}{*}{ Age } & $-0.27^{* * *}$ & -0.02 & $0.10^{* * *}$ & -0.03 \\
\hline & $(0.03)$ & $(0.03)$ & $(0.02)$ & $(0.02)$ \\
\hline \multirow[t]{2}{*}{ Female } & -0.11 & $4.04^{* * *}$ & $2.21^{* * *}$ & $3.45^{* * *}$ \\
\hline & $(0.66)$ & $(0.65)$ & $(0.61)$ & $(0.61)$ \\
\hline \multirow[t]{2}{*}{ Medium education } & 1.56 & 1.11 & 0.03 & 1.45 \\
\hline & $(1.09)$ & $(1.08)$ & $(1.02)$ & $(1.02)$ \\
\hline \multirow{2}{*}{ High education } & 1.92 & -1.20 & -1.83 & $2.93^{* *}$ \\
\hline & $(1.08)$ & $(1.07)$ & $(1.00)$ & $(1.00)$ \\
\hline $\mathrm{R}^{2}$ & 0.07 & 0.05 & 0.20 & 0.07 \\
\hline Adj. $R^{2}$ & 0.07 & 0.04 & 0.19 & 0.07 \\
\hline Num. obs. & 2943 & 2949 & 2940 & 2949 \\
\hline
\end{tabular}

Table 1 shows the results from the main set of regressions. Even after control-

\footnotetext{
${ }^{13}$ The correlations of media exposure with the four outcome variables ranged from $r=0.09$ to $r=0.15$.
} 

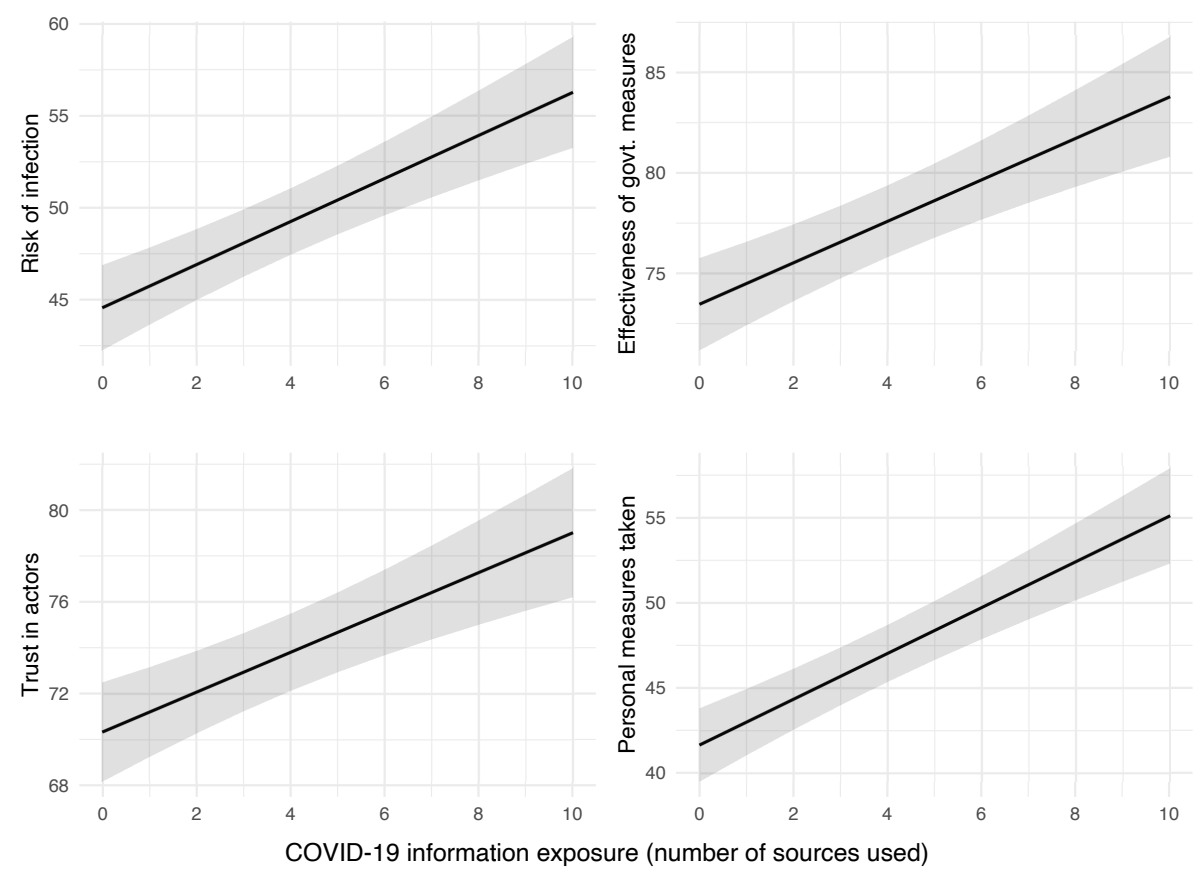

Figure 3: Predicted values of COVID-19 information exposure on COVID-19 outcomes with $95 \%$ confidence intervals, based on Table 1. All other variables were held constant, or in the case of discrete variables such as education, at their proportions.

ling for a host of confounders, getting information from more sources had a statistically significant positive association with COVID-19 outcomes $(p<0.001)$. This relationship was consistent for perceived risks of an infection, the perceived effectiveness of government measures, trust in actors and compliance with measures to mitigate COVID-19.

To get a better sense of the magnitude of these statistical relationships, Figure 3 shows the predicted values (marginal effects) of the main independent variable COVID-19 information exposure on the four outcome variables. There are apparent differences in the baseline levels, as perceptions of the risks of infection and the number of personal measures are distributed around a mean of 50, whereas trust in actors and perceptions of the effectiveness of government measures were generally higher on a scale from 0 to 100. An additional source of COVID-19 information was associated with 1.34 more additional behavioural measures and risks perceptions that are 1.17 points higher. Even for the two dependent outcomes with less variance, the effect sizes are a 1.03 points higher belief in the effectiveness of government measures and a 0.87 points higher trust for each additional information source. 
Robustness tests in Online Appendix Section 5 show results disaggregated by information source. For all different types of information exposure, the effects were consistently positive (and oftentimes statistically significant), with a negative effect of personal conversations on the evaluation of government measures being the lone exception to this pattern. In none of these models did more exposure to COVID-19 on social media (or in additional models, only Facebook) have statistically significant negative effects on the outcome variables. ${ }^{14}$ Taken together, information exposure, including social media, has an overall positive statistical relation with four different outcome dimensions that all play a crucial role in mitigation efforts against the pandemic.

\section{Were there differences in the coverage of COVID-19 be- tween information sources?}

In the second part of the analysis, we investigate whether there were differences in the COVID-19 coverage of different providers of information (RQ3). For this analysis, we mapped the top coded 1,000 Facebook pages to the information sources present in the GESIS Panel survey where applicable (e.g., https://www.facebook.com/tagesschau was assigned to the category 'national public broadcasting'). To approximate the COVID-19 information exposure on Facebook that respondents were asked about in the survey, we constructed the category 'Other sources' which contained posts by a wide range of different actors, including comedians and celebrities, politicians (e.g., prominent AfD politicians), so-called 'alternative media' (such as RT Deutsch), government accounts or German-speaking accounts from other countries (such as Austrian Chancellor Sebastian Kurz). The top 40 pages ranked by the number of interactions their COVID-19 posts received can be found in Online Appendix Section 4.

Most of the resulting topics from our topic model were semantically coherent and could be substantially interpreted. However, (short) social media texts from heterogeneous sources contain more peculiar language compared with structured corpora such as newspaper articles. Therefore, the topic model also identified some very small and inconsistent topics, mostly shaped by idiosyncratic wording or repeated hashtag use by one or two particular pages. After extensive manual inspection, we therefore selected only the more relevant topics for further analysis, concretely, all topics with a mean probability of at least 0.01 , averaged across all documents. ${ }^{15}$ The remaining 13 (out of 20) topics were labelled by three authors based on the most predictive terms for each topic (see Table 2) and a manual inspection of a large random sample of Facebook posts with a high probability for each topic (see some examples in Table A5 in the Online Appendix). The probabilities of each topic were then aggregated for each information source that was also present in the survey.

\footnotetext{
${ }^{14}$ The exception being a non-significant negative impact of social media use on trust in political actors.

${ }^{15}$ For instance, 'Local information West Germany' is a very small topic that barely cleared the 0.01 threshold. It can be conceptually subsumed under 'Practical local information'.
} 
Table 2: Top terms per topic and description.

\begin{tabular}{|c|c|c|}
\hline Topic & Top 10 terms & Description \\
\hline $\begin{array}{l}\text { Early outbreak } \\
\& \text { uncertainty }\end{array}$ & $\begin{array}{l}\text { welt, infizieren, wichtig, } \\
\text { menschen, fragen, } \\
\text { deutschland, china, virus, } \\
\text { zeigen, aktuell }\end{array}$ & $\begin{array}{l}\text { Information about the early } \\
\text { outbreak and reduction of } \\
\text { uncertainty regarding the } \\
\text { virus }\end{array}$ \\
\hline $\begin{array}{l}\text { Government } \\
\text { measures }\end{array}$ & $\begin{array}{l}\text { bleiben, maßnahmen, stadt, } \\
\text { gelten, schulen, schließen, } \\
\text { ausbreitung, aktuell, } \\
\text { menschen, öffentlich }\end{array}$ & $\begin{array}{l}\text { Policy measures, their } \\
\text { impact on daily life and } \\
\text { their effectiveness }\end{array}$ \\
\hline $\begin{array}{l}\text { Health care } \\
\text { system }\end{array}$ & $\begin{array}{l}\text { kontakt, versorgung, } \\
\text { patienten, alt, menschen, } \\
\text { schützen, personal, } \\
\text { krankenhäuser, medizinisch, } \\
\text { ärzte }\end{array}$ & $\begin{array}{l}\text { Preparedness of the health } \\
\text { care system, at-risk-groups, } \\
\text { personal hygiene }\end{array}$ \\
\hline $\begin{array}{l}\text { Impact on } \\
\text { economy }\end{array}$ & $\begin{array}{l}\text { deutsch, folgen, milliarden, } \\
\text { geld, prozent, wirtschaft, } \\
\text { euro, krise, unternehmen, } \\
\text { wirtschaftlich }\end{array}$ & $\begin{array}{l}\text { Impact of COVID-19 on } \\
\text { the national and } \\
\text { international economy }\end{array}$ \\
\hline $\begin{array}{l}\text { Local \& } \\
\text { personal stories }\end{array}$ & $\begin{array}{l}\text { bestätigen, infizieren, } \\
\text { menschen, kreis, positiv, } \\
\text { frau, testen, personen, } \\
\text { häuslich, mann }\end{array}$ & $\begin{array}{l}\text { Local impact with strong } \\
\text { focus on individual } \\
\text { infections or clusters }\end{array}$ \\
\hline $\begin{array}{l}\text { Local } \\
\text { information }\end{array}$ & $\begin{array}{l}\text { aachen, krisenstäbe, } \\
\text { städteregion, stadt, lage, }\end{array}$ & $\begin{array}{l}\text { Local COVID-19 news, } \\
\text { very similar to "Practical }\end{array}$ \\
\hline West Germany & $\begin{array}{l}\text { koblenz, märz, insgesamt, } \\
\text { aktuell }\end{array}$ & local information" \\
\hline Media events & $\begin{array}{l}\mathrm{dr} \text {, erklären, sprechen, } \\
\text { fragen, kommentare, live, } \\
\text { interview, beantworten, } \\
\text { pressekonferenz, prof }\end{array}$ & $\begin{array}{l}\text { Announcements (or results) } \\
\text { of discussion rounds, expert } \\
\text { opinions, press briefings } \\
\text { and TV shows }\end{array}$ \\
\hline $\begin{array}{l}\text { National } \\
\text { political actors }\end{array}$ & $\begin{array}{l}\text { kanzlerin, deutsch, grenzen, } \\
\text { regierung, spahn, angela, } \\
\text { deutschland, } \\
\text { bundesregierung, cdu, merkel }\end{array}$ & $\begin{array}{l}\text { Speeches and nation-wide } \\
\text { decision making }\end{array}$ \\
\hline $\begin{array}{l}\text { Postponement } \\
\text { of events }\end{array}$ & $\begin{array}{l}\text { aufgrund, stattfinden, } \\
\text { geplant, finden, märz, foto, } \\
\text { april, verschieben, absagen, } \\
\text { veranstaltungen }\end{array}$ & $\begin{array}{l}\text { Cancellation and } \\
\text { postponement of events in } \\
\text { sports, culture, leisure, } \\
\text { entertainment }\end{array}$ \\
\hline $\begin{array}{l}\text { Practical local } \\
\text { information }\end{array}$ & $\begin{array}{l}\text { thema, informationen, bitte, } \\
\text { hotline, kreis, fragen, direkt, } \\
\text { wichtig, finden, aktuell }\end{array}$ & $\begin{array}{l}\text { Practical information and } \\
\text { where to turn for help for } \\
\text { residents of specific regions }\end{array}$ \\
\hline $\begin{array}{l}\text { Solidarity \& } \\
\text { encouragement }\end{array}$ & $\begin{array}{l}\text { bleiben, helfen, zeiten, } \\
\text { menschen, einfach, leben, } \\
\text { hause, mein, halten, mal }\end{array}$ & $\begin{array}{l}\text { Moral appeals, empathy, } \\
\text { community hashtag } \\
\text { campaigns }\end{array}$ \\
\hline $\begin{array}{l}\text { Supplies \& } \\
\text { shortages }\end{array}$ & $\begin{array}{l}\text { supermärkten, kaufen, } \\
\text { polizei, desinfektioidmittel, } \\
\text { leeren, lebensmittel, } \\
\text { toilettenpapier, kunden, } \\
\text { hamsterkäufe, regale }\end{array}$ & $\begin{array}{l}\text { Supplies and their shortage, } \\
\text { including hoarding; also } \\
\text { includes warnings about } \\
\text { scams }\end{array}$ \\
\hline $\begin{array}{l}\text { Travel and } \\
\text { international } \\
\text { developments }\end{array}$ & $\begin{array}{l}\text { zahl, deutsch, infizieren, } \\
\text { menschen, italien, wuhan, } \\
\text { deutschland, china, virus, } \\
\text { fälle }\end{array}$ & $\begin{array}{l}\text { Developments in other } \\
\text { countries; travel restrictions }\end{array}$ \\
\hline
\end{tabular}




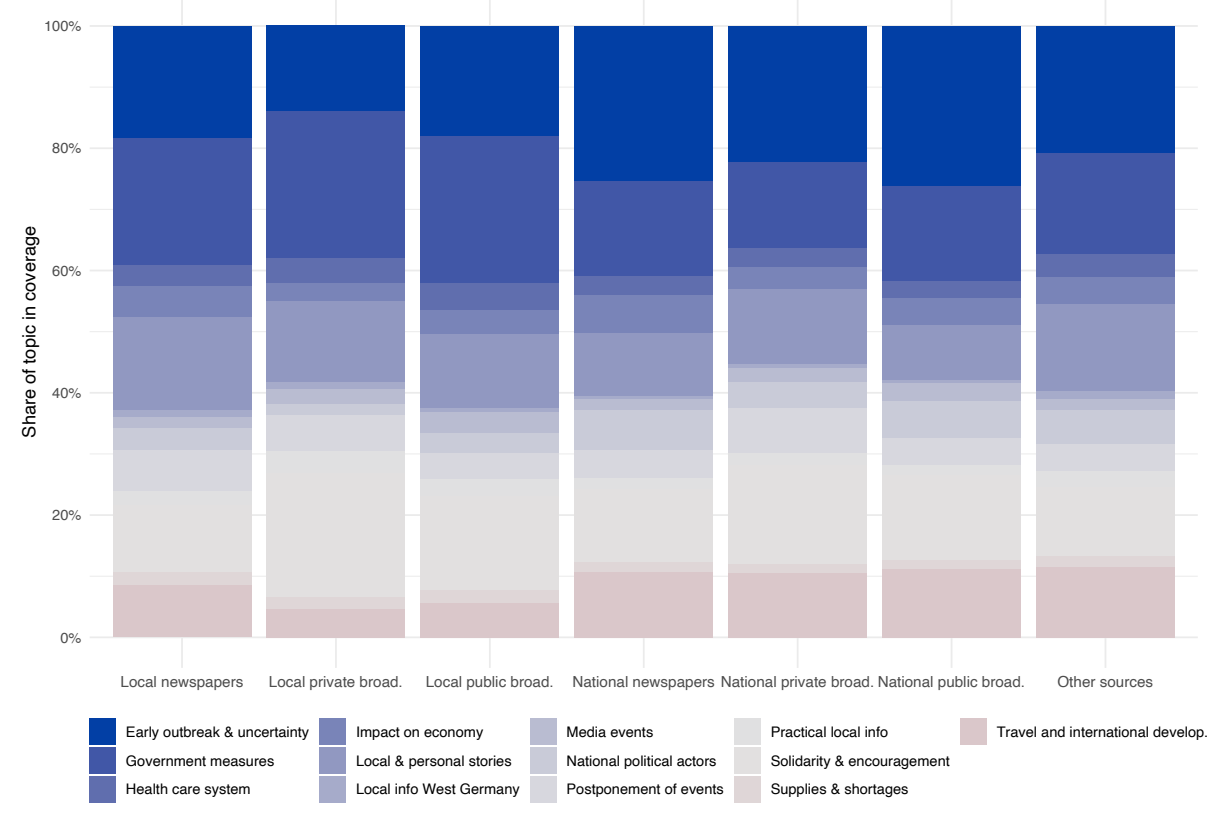

Figure 4: Mean topic probabilities per information source.

Figure 4 shows the prevalence of the 13 topics across information sources. Some deviations can be found among local private and public broadcasters that put a stronger emphasis on the encouragement of citizens to stay at home and to foster a sense of community. Local outlets also focused more on concrete implemented measures, which can differ substantially between regions in Germany. National media, on the other hand, were over-proportionally reporting on the early outbreak and uncertainty about the nature of the disease. Overall, there is only slight variation, as the topics have similar proportions across information sources, even in the category 'Other sources' which represents the great variety of content on COVID-19 found on Facebook. The homogeneity of Facebook contents might be one of the reasons why we could not detect much effect heterogeneity in the attitudes and behaviours related to COVID-19 depending on the information source in the survey-based analysis. In March 2020, under high uncertainty regarding the nature of the disease, even the AfD advocated for more stringent measures against COVID-19, whereas discussions about government overreach and the negative effects of lockdowns were only in their infancy.

Of course, homogeneity on the level of topics still masks more nuanced latent dimensions such as the framing or valence of coverage on COVID-19. For instance, topics with a pronounced anti-establishment perspective were prominent in the specifically tailored corpus of Boberg et al. (2020) where alternative media were over-represented compared to the broader and more 'mainstream' sample 
we analysed here. Public Facebook information on COVID-19 shaped by institutional actors, media outlets, and prominent societal figures that garnered most of the attention is very unlikely to contain disinformation or misinformation. The data shows support for this, first, through the absence of a topical cluster of posts that would question the severity of the pandemic. Neither of the models we ran with different parameter specifications produced such a topic. Second, we manually searched for slanted terms such as *lüge*, Wahrheit, *fakten*, Realität, *gates* or *querdenken in the posts of Other sources, yet found no noteworthy instances of misinformation or disinformation.

\section{Conclusion}

This paper comprehensively investigated information exposure during the first wave of COVID-19 in Germany in March 2020. First, using high-quality survey data from the GESIS Panel, we descriptively showed that established sources such as public broadcasters were the primary pathways for getting COVID-19 information, albeit a much less pronounced use of social media. Second, we found a strong statistical relationship between the number of information sources used and positive outcomes from a public health perspective; i.e., pronounced perceptions of risks amid considerable uncertainty, trust in central actors and the effectiveness of government measures and ultimately, (self-reported) compliance with measures. There were also no indications for negative effects of social media or Facebook more specifically. As we were using data only from the online component of the GESIS Panel, the overall share of social media in Germans' COVID-19 information diet was most likely even smaller. Third, an automated analysis of more than 800,000 German Facebook posts on COVID-19 by the most popular public pages showed that coverage was generally emphasising the dangers posed by the novel virus. At least on this scale of data collection and analysis, we could not find noteworthy traces of misinformation and/or disinformation. Taken together, the findings suggest that a high saturation of media coverage in citizens' daily lives can help in the efforts to effectively mitigate the pandemic. The reach and quality of information will also play a crucial role in the next stage of the pandemic with vaccines becoming available for wider parts of the population.

Nonetheless, our analysis has several limitations. Most importantly, even strong statistical findings from cross-sectional survey data do not causally prove that information exposure improves public health outcomes. In addition to possible confounders which we did not include or that generally cannot be measured with self-reports, there is also the issue of reversed causality. Someone with high risk perceptions should also be more likely to search for COVID-19 information. At the same time, the reversed causal mechanisms are less apparent for the other three outcomes, where the relationships were equally strong. We also acknowledge limitations in measurements, as self-reports of media exposure have a limited validity (Scharkow 2016). The measures we used did also not allow for assessing the (daily, weekly) intensity of exposure. The most promising 
research design to mitigate these limitations is to link surveys and direct measures of (digital) behaviour collected for the same set of individuals (Stier et al. 2020a). While Facebook served our comparative purposes well as many different media outlets also publish news on the social network site, this data source only captures parts of the overall amount of information that reaches citizens via diverse distribution channels such as television, print newspapers, or Telegram groups.

The final limitation pertains to the nature of the specific case and time period under study. There was almost no politicisation of COVID-19 and the government measures taken in Germany during the first wave. Since then, the negative social and economic effects of lockdowns have been much more prominently featured in public debates. In addition, a host of political actors such as the AfD and the 'Querdenken' movement downplay the threats posed by the virus and mobilise against government measures. With these shifts in media coverage and political actors' stances, the signals in publicly available information on COVID-19 have become more ambiguous. As a consequence, how information exposure relates to COVID-19 perceptions, attitudes and behaviours has likely become more contingent on political predispositions (such as being a supporter of a populist radical right party) and individual characteristics. Therefore, the character and correlates of COVID-19 information exposure remain important subjects to study.

\section{References}

Allen, Jennifer, Baird Howland, Markus Mobius, David Rothschild, and Duncan J. Watts. 2020. "Evaluating the Fake News Problem at the Scale of the Information Ecosystem." Science Advances 6 (14): eaay3539.

Andersen, Kim, Claes H. de Vreese, and Erik Albæk. 2016. "Measuring Media Diet in a High-Choice Environment - Testing the List-Frequency Technique." Communication Methods and Measures 10 (2-3): 81-98.

Antoun, Christopher. 2015. "Who Are the Internet Users, Mobile Internet Users, and Mobile-Mostly Internet Users?: Demographic Differences across InternetUse Subgroups in the U.S." In Mobile Research Methods: Opportunities and Challenges of Mobile Research Methodologies, edited by Daniele Toninelli, Robert Pinter, and Pabl de Pedraza. Ubiquity Press.

Ash, Elliott, Sergio Galletta, Dominik Hangartner, Yotam Margalit, and Matteo Pinna. 2020. "The effect of Fox News on health behavior during COVID-19." SSRN Electronic Journal .

Beckmann, Katharina, Axel Glemser, Christiane Heckel, Christian von der Heyde, Jürgen H. P. Hoffmeyer-Zlotnik, Ute Hanefeld, Robert Herter-Eschweiler, and Carola Kühnen. 2016. Demographische Standards. Eine Gemeinsame Empfehlung Des ADM, Arbeitskreis Deutscher Markt- 
Und Sozialforschungsinstitute e.V., Der Arbeitsgemeinschaft Sozialwissenschaftlicher Institute e.V. (ASI) Und Des Statistischen Bundesamtes. 6th ed. Wiesbaden.

Beisch, Natalie, and Carmen Schäfer. 2020. "Ergebnisse der ARD/ZDFOnlinestudie 2020. Internetnutzung mit großer Dynamik: Medien, Kommunikation, Social Media." Media Perspektiven 9/2020 462-481.

Boberg, Svenja, Thorsten Quandt, Tim Schatto-Eckrodt, and Lena Frischlich. 2020. "Pandemic Populism: Facebook Pages of Alternative News Media and the Corona Crisis - A Computational Content Analysis." .

Bosnjak, Michael, Tanja Dannwolf, Tobias Enderle, Ines Schaurer, Bella Struminskaya, Angela Tanner, and Kai W. Weyandt. 2018. "Establishing an Open Probability-Based Mixed-Mode Panel of the General Population in Germany: The GESIS Panel." Social Science Computer Review 36 (1): 103-115.

CrowdTangle Team. 2020. "CrowdTangle." CrowdTangle. Facebook, Menlo Park, California, United States. List ID: 1401737.

Edelman. 2020. "Edelman Trust Barometer Special Report." https ://www . amanewyork.org/wp-content/ uploads/2020/04/20.EdelmanTrustBarometer.

CoronavirusSpecialReportTrustAndTheCoronavirus .pdf.

Flaxman, Seth, Swapnil Mishra, Axel Gandy, H. Juliette T. Unwin, Thomas A. Mellan, Helen Coupland, Charles Whittaker, et al. 2020. "Estimating the effects of non-pharmaceutical interventions on COVID-19 in Europe." Nature 584 (7820): 257-261.

GESIS. 2020a. "GESIS Panel Extended Edition." GESIS Data Archive, Cologne. ZA5664 Data file Version 37.0.0, https://doi.org/10.4232/1.13572.

GESIS. 2020b. "GESIS Panel Standard Edition." GESIS Data Archive, Cologne. ZA5664 Data file Version 37.0.0, https://doi.org/10.4232/1.13573.

GESIS Panel Team. 2020. "GESIS Panel Special Survey on the Coronavirus SARS-CoV-2 Outbreak in Germany." GESIS Data Archive, Cologne. ZA5667 Data file Version 1.1.0, https://doi.org/10.4232/1.13520.

Guess, Andrew M. forthcoming. "(Almost) Everything in Moderation: New Evidence on Americans' Online Media Diets." American Journal of Political Science.

Guess, Andrew M., Jonathan Nagler, and Joshua Tucker. 2019. "Less than you think: Prevalence and predictors of fake news dissemination on Facebook." Science Advances 5 (1). 
Hameleers, Michael, Toni G. L. A. van der Meer, and Anna Brosius. 2020. "Feeling "disinformed" lowers compliance with COVID-19 guidelines: Evidence from the US, UK, Netherlands and Germany." Harvard Kennedy School Misinformation Review .

Hart, P. Sol, Sedona Chinn, and Stuart Soroka. 2020. "Politicization and Polarization in COVID-19 News Coverage." Science Communication 42 (5): 679697 .

Honnibal, Matthew, Ines Montani, Sofie Van Landeghem, and Adriane Boyd. 2020. "spaCy: Industrial-strength Natural Language Processing in Python." https://doi.org/10.5281/zenodo.1212303.

Imhoff, Roland, and Pia Lamberty. 2020. "A Bioweapon or a Hoax? The Link Between Distinct Conspiracy Beliefs About the Coronavirus Disease (COVID19) Outbreak and Pandemic Behavior." Social Psychological and Personality Science 11 (8): 1110-1118.

Newman, Nic, Richard Fletcher, Anne Schulz, Simge Andı, and Rasmus Kleis Nielsen. 2020. "Reuters Institute Digital News Report 2020." https://reutersinstitute.politics.ox.ac.uk/sites/default/ files/2020-06/DNR_2020_FINAL.pdf.

Nielsen, Rasmus Kleis, Richard Fletcher, Nic Newman, J. Scott Brennen, and Philip N. Howard. 2020. "Navigating the 'Infodemic': How People in Six Countries Access and Rate News and Information about Coronavirus." https://reutersinstitute.politics.ox.ac.uk/sites/default/files/ 2020-04/Navigating\%20the\%20Coronavirus\%20Infodemic\%20FINAL.pdf.

Quandt, Thorsten, Svenja Boberg, Tim Schatto-Eckrodt, and Lena Frischlich. 2020. "Pandemic News: Facebook Pages of Mainstream News Media and the Coronavirus Crisis - A Computational Content Analysis." .

Rammstedt, Beatrice, Clemens M. Lechner, and Bernd Weiß. 2021. "Personality and the Pandemic: Does Personality Predict Responses to the COVID-19 Crisis?" European Journal of Personality (in press).

Řehůřek, Radim, and Petr Sojka. 2010. "Software Framework for Topic Modelling with Large Corpora." In Proceedings of the LREC 2010 Workshop on New Challenges for NLP Frameworks, Valletta, Malta, May, 45-50. ELRA.

Röder, Michael, Andreas Both, and Alexander Hinneburg. 2015. "Exploring the Space of Topic Coherence Measures." In Proceedings of the Eighth ACM International Conference on Web Search and Data Mining, WSDM '15, New York, NY, USA, 399-408. Association for Computing Machinery.

Rothmund, Tobias, Fahima Farkhari, Flavio Azevedo, and Carolin-Theresa Ziemer. 2020. "Scientific Trust, Risk Assessment, and Conspiracy Beliefs about COVID-19 - Four Patterns of Consensus and Disagreement between Scientific Experts and the German Public." Jul. psyarxiv.com/4nzuy. 
Scharkow, Michael. 2016. "The Accuracy of Self-Reported Internet Use? A Validation Study Using Client Log Data." Communication Methods and Measures 10 (1): $13-27$.

Scharkow, Michael, Frank Mangold, Sebastian Stier, and Johannes Breuer. 2020. "How social network sites and other online intermediaries increase exposure to news." Proceedings of the National Academy of Sciences 117: 2761-2763.

Schaurer, Ines, and Bernd Weiß. 2020. "Investigating Selection Bias of Online Surveys on Coronavirus-Related Behavioral Outcomes: An Example Utilizing the GESIS Panel Special Survey on the Coronavirus SARS-CoV-2 Outbreak in Germany." Survey Research Methods 2 (14): 103-108.

Siebenhaar, Katharina U., Anja K. Köther, and Georg W. Alpers. 2020. "Dealing With the COVID-19 Infodemic: Distress by Information, Information Avoidance, and Compliance With Preventive Measures." Frontiers in Psychology 11.

Simonov, Andrey, Szymon K Sacher, Jean-Pierre H Dubé, and Shirsho Biswas. 2020. The Persuasive Effect of Fox News: Non-Compliance with Social Distancing During the Covid-19 Pandemic. Working Paper 27237. National Bureau of Economic Research. http://www.nber.org/papers/w27237.

Statistisches Bundesamt. 2020. "GENESIS Table 12411-0006: Bevölkerung: Deutschland, Stichtag, Altersjahre, Nationalität/Geschlecht/Familienstand." https://www-genesis.destatis.de/genesis//online?operation= table\&code $=12411-0006 \&$ bypass $=$ true\&levelindex $=1 \& l$ evelid $=$ 1600145907092\#abreadcrumb.

Stier, Sebastian, Johannes Breuer, Pascal Siegers, and Kjerstin Thorson. 2020a. "Integrating Survey Data and Digital Trace Data: Key Issues in Developing an Emerging Field." Social Science Computer Review 38 (5): 503-516.

Stier, Sebastian, Nora Kirkizh, Caterina Froio, and Ralph Schroeder. 2020b. "Populist Attitudes and Selective Exposure to Online News: A Cross-Country Analysis Combining Web Tracking and Surveys." The International Journal of Press/Politics 25 (3): 426-446.

Yan, Xiaohui, Jiafeng Guo, Yanyan Lan, and Xueqi Cheng. 2013. "A Biterm Topic Model for Short Texts." In Proceedings of the 22nd International Conference on World Wide Web, WWW '13, New York, NY, USA, 1445-1456. Association for Computing Machinery. 
The role of information exposure during the first COVID-19 wave in Germany: Evidence from survey and Facebook data

ONLINE APPENDIX

Anonymous

\section{Contents}

1 Sample composition $\quad 2$

2 Survey items $\quad 3$

3 Descriptive statistics $\quad 16$

4 Additional details on the text analysis $\quad 18$

5 Additional regression models $\quad 29$

$\begin{array}{ll}\text { References } & 31\end{array}$ 


\section{Sample composition}

Table A1: Comparison of study sample with Microcensus data (in percent).

\begin{tabular}{lcc}
\hline Group & Microcensus & Study sample \\
\hline 16-29 years & 17.68 & 6.83 \\
30-44 years & 20.16 & 23.23 \\
45-59 years & 28.20 & 36.21 \\
60 or older & 33.96 & 33.73 \\
Low education & 37.74 & 10.91 \\
Medium education & 30.36 & 31.08 \\
High education & 31.90 & 58.02 \\
Female & 51.26 & 49.03 \\
\hline
\end{tabular}

Note:

German Microcensus data for the year 2017 (Destatis 2018). Statistics are based on respondents participating in the baseline demographic survey. 


\section{Survey items}

Table A2: Survey items used in the analysis.

\begin{tabular}{ll}
\hline Construct & Item text (German/English) \\
\hline $\begin{array}{l}\text { COVID-19 } \\
\text { information exposure }\end{array}$ & $\begin{array}{l}\text { Aus welchen Quellen beziehen Sie aktue } \\
\text { Informationen zum Coronavirus? }\end{array}$ \\
& $\begin{array}{l}\text { From which sources do you get current } \\
\text { information about the coronavirus? }\end{array}$
\end{tabular}

information about the coronavirus?

Wie wahrscheinlich ist es Ihrer Meinung nach, dass in den nächsten 2 Monaten ... Sie mit dem Coronavirus infiziert werden?

How likely is it in your opinion that in the next two months ... you get infected with the coronavirus?
Value labels (German/English)

Überregionales öffentlich-rechtliches Fernsehen

oder Radio (z. B. ARD, ZDF,

Deutschlandfunk); Überregionales privates

Fernsehen oder Radio (z. B. RTL, Sat1,

ProSieben); Überregionale Zeitungen (z. B.

Süddeutsche Zeitung, Die Welt, FAZ); Lokales öffentlich-rechtliches Fernsehen oder Radio (z.

B. HR, WDR, RBB); TV oder Radio; Lokales privates Fernsehen oder Radio (z. B. regio TV, Radio Köln); Lokalzeitungen; Facebook; Weitere soziale Medien (z. B. Instagram, Twitter);

Persönliche Gespräche mit Freunden und

Familie; Sonstiges

National public television or radio (e.g., ARD, ZDF, Deutschlandfunk); National private

television or radio (e.g., RTL, Sat1, ProSieben); National newspapers (e.g., Süddeutsche Zeitung, Die Welt, FAZ); Local public television or radio (e.g., HR, WDR, RBB); Local private television or radio (e.g., regio TV, Radio Cologne); Local newspapers; Other social media (e.g., Instagram, Twitter); Personal conversations with friends and family; Other

Überhaupt nicht wahrscheinlich; Sehr unwahrscheinlich; Eher unwahrscheinlich; Mittelmäßig wahrscheinlich; Eher wahrscheinlich; Sehr wahrscheinlich; Absolut wahrscheinlich; Das ist bereits passiert.

Not at all likely; Very unlikely; Rather unlikely; Moderately likely; Rather likely; Very likely; Absolutely likely; This has already happened.
GESIS Panel variable hzcy084a-hzcy093a,

hzcy095a

hzcy001a 
Table A2: Survey items used in the analysis. (continued)

\begin{tabular}{|c|c|c|c|}
\hline Construct & Item text (German/English) & Value labels (German/English) & GESIS Panel variable \\
\hline Risk perceptions & $\begin{array}{l}\text { Wie wahrscheinlich ist es Ihrer Meinung nach, } \\
\text { dass in den nächsten } 2 \text { Monaten ... jemand aus } \\
\text { ihrem direkten Umfeld (Familie, Freunde, } \\
\text { Kollegen) mit dem Coronavirus infiziert wird? } \\
\text { How likely is it in your opinion that in the next } \\
\text { two months ... someone from your close social } \\
\text { surroundings (family, friends, colleagues) gets } \\
\text { infected with the coronavirus? }\end{array}$ & $\begin{array}{l}\text { Überhaupt nicht wahrscheinlich; Sehr } \\
\text { unwahrscheinlich; Eher unwahrscheinlich; } \\
\text { Mittelmäßig wahrscheinlich; Eher } \\
\text { wahrscheinlich; Sehr wahrscheinlich; Absolut } \\
\text { wahrscheinlich; Das ist bereits passiert. } \\
\text { Not at all likely; Very unlikely; Rather unlikely; } \\
\text { Moderately likely; Rather likely; Very likely; } \\
\text { Absolutely likely; This has already happened. }\end{array}$ & hzcy002a \\
\hline Risk perceptions & $\begin{array}{l}\text { Wie wahrscheinlich ist es Ihrer Meinung nach, } \\
\text { dass in den nächsten } 2 \text { Monaten ... Sie stationär } \\
\text { im Krankenhaus behandelt werden müssen, falls } \\
\text { Sie sich mit dem Coronavirus infizieren? } \\
\text { How likely is it in your opinion that in the next } \\
\text { two months ... you need to be hospitalized in } \\
\text { case you get infected with the coronavirus? }\end{array}$ & $\begin{array}{l}\text { Überhaupt nicht wahrscheinlich; Sehr } \\
\text { unwahrscheinlich; Eher unwahrscheinlich; } \\
\text { Mittelmäßig wahrscheinlich; Eher } \\
\text { wahrscheinlich; Sehr wahrscheinlich; Absolut } \\
\text { wahrscheinlich; Das ist bereits passiert. } \\
\text { Not at all likely; Very unlikely; Rather unlikely; } \\
\text { Moderately likely; Rather likely; Very likely; } \\
\text { Absolutely likely; This has already happened. }\end{array}$ & hzcy003a \\
\hline Risk perceptions & $\begin{array}{l}\text { Wie wahrscheinlich ist es Ihrer Meinung nach, } \\
\text { dass in den nächsten } 2 \text { Monaten ... Sie wegen des } \\
\text { Coronavirus unter Quarantäne gestellt werden, } \\
\text { unabhängig davon, ob Sie infiziert sind oder } \\
\text { nicht? }\end{array}$ & $\begin{array}{l}\text { Überhaupt nicht wahrscheinlich; Sehr } \\
\text { unwahrscheinlich; Eher unwahrscheinlich; } \\
\text { Mittelmäßig wahrscheinlich; Eher } \\
\text { wahrscheinlich; Sehr wahrscheinlich; Absolut } \\
\text { wahrscheinlich; Das ist bereits passiert. }\end{array}$ & hzcy004a \\
\hline & $\begin{array}{l}\text { How likely is it in your opinion that in the next } \\
\text { two months ... you get quarantined for the } \\
\text { coronavirus, whether you are infected or not? }\end{array}$ & $\begin{array}{l}\text { Not at all likely; Very unlikely; Rather unlikely; } \\
\text { Moderately likely; Rather likely; Very likely; } \\
\text { Absolutely likely; This has already happened. }\end{array}$ & \\
\hline
\end{tabular}


Table A2: Survey items used in the analysis. (continued)

\begin{tabular}{|c|c|c|c|}
\hline Construct & Item text (German/English) & Value labels (German/English) & GESIS Panel variable \\
\hline Risk perceptions & $\begin{array}{l}\text { Wie wahrscheinlich ist es Ihrer Meinung nach, } \\
\text { dass in den nächsten } 2 \text { Monaten ... Sie mit dem } \\
\text { Coronavirus infiziert werden und andere } \\
\text { Personen anstecken? } \\
\text { How likely is it in your opinion that in the next } \\
\text { two months ... you get infected with the } \\
\text { coronavirus and spread it to other people? }\end{array}$ & $\begin{array}{l}\text { Überhaupt nicht wahrscheinlich; Sehr } \\
\text { unwahrscheinlich; Eher unwahrscheinlich; } \\
\text { Mittelmäßig wahrscheinlich; Eher } \\
\text { wahrscheinlich; Sehr wahrscheinlich; Absolut } \\
\text { wahrscheinlich; Das ist bereits passiert. } \\
\text { Not at all likely; Very unlikely; Rather unlikely; } \\
\text { Moderately likely; Rather likely; Very likely; } \\
\text { Absolutely likely; This has already happened. }\end{array}$ & hzcy005a \\
\hline $\begin{array}{l}\text { Effectiveness of } \\
\text { government measures }\end{array}$ & $\begin{array}{l}\text { Wie wirksam sind Ihrer Meinung nach die } \\
\text { folgenden politischen Maßnahmen zur } \\
\text { Bekämpfung der weiteren Verbreitung des } \\
\text { Coronavirus? Schließung von Kitas, } \\
\text { Kindergärten und Schulen } \\
\text { How effective are the following policies in } \\
\text { fighting the further spread of the coronavirus in } \\
\text { your opinion? Closure of day-care centres, } \\
\text { kindergartens and schools }\end{array}$ & $\begin{array}{l}\text { Überhaupt nicht wirksam; Wenig wirksam; } \\
\text { Teils/ teils; Ziemlich wirksam; Sehr wirksam } \\
\text { Not effective at all; Not very effective; Partly; } \\
\text { Quite effective; Very effective }\end{array}$ & hzcy019a \\
\hline $\begin{array}{l}\text { Effectiveness of } \\
\text { government measures }\end{array}$ & $\begin{array}{l}\text { Wie wirksam sind Ihrer Meinung nach die } \\
\text { folgenden politischen Maßnahmen zur } \\
\text { Bekämpfung der weiteren Verbreitung des } \\
\text { Coronavirus? Schließung von Sportvereinen und } \\
\text { Fitnesszentren } \\
\text { How effective are the following policies in } \\
\text { fighting the further spread of the coronavirus in } \\
\text { your opinion? Closure of sports clubs and fitness } \\
\text { centres }\end{array}$ & $\begin{array}{l}\text { Überhaupt nicht wirksam; Wenig wirksam; } \\
\text { Teils / teils; Ziemlich wirksam; Sehr wirksam } \\
\text { Not effective at all; Not very effective; Partly; } \\
\text { Quite effective; Very effective }\end{array}$ & hzcy020a \\
\hline
\end{tabular}


Table A2: Survey items used in the analysis. (continued)

\begin{tabular}{|c|c|c|c|}
\hline Construct & Item text (German/English) & Value labels (German/English) & GESIS Panel variable \\
\hline $\begin{array}{l}\text { Effectiveness of } \\
\text { government measures }\end{array}$ & $\begin{array}{l}\text { Wie wirksam sind Ihrer Meinung nach die } \\
\text { folgenden politischen Maßnahmen zur } \\
\text { Bekämpfung der weiteren Verbreitung des } \\
\text { Coronavirus? Schließung von Bars, Cafés und } \\
\text { Restaurants } \\
\text { How effective are the following policies in } \\
\text { fighting the further spread of the coronavirus in } \\
\text { your opinion? Closure of bars, cafés and } \\
\text { restaurants }\end{array}$ & $\begin{array}{l}\text { Überhaupt nicht wirksam; Wenig wirksam; } \\
\text { Teils/ teils; Ziemlich wirksam; Sehr wirksam } \\
\text { Not effective at all; Not very effective; Partly; } \\
\text { Quite effective; Very effective }\end{array}$ & hzcy021a \\
\hline $\begin{array}{l}\text { Effectiveness of } \\
\text { government measures }\end{array}$ & $\begin{array}{l}\text { Wie wirksam sind Ihrer Meinung nach die } \\
\text { folgenden politischen Maßnahmen zur } \\
\text { Bekämpfung der weiteren Verbreitung des } \\
\text { Coronavirus? Schließung aller Geschäfte mit } \\
\text { Ausnahme von Supermärkten und Apotheken } \\
\text { How effective are the following policies in } \\
\text { fighting the further spread of the coronavirus in } \\
\text { your opinion? Closure of all shops except } \\
\text { supermarkets and pharmacies }\end{array}$ & $\begin{array}{l}\text { Überhaupt nicht wirksam; Wenig wirksam; } \\
\text { Teils / teils; Ziemlich wirksam; Sehr wirksam } \\
\text { Not effective at all; Not very effective; Partly; } \\
\text { Quite effective; Very effective }\end{array}$ & hzcy022a \\
\hline $\begin{array}{l}\text { Effectiveness of } \\
\text { government measures }\end{array}$ & $\begin{array}{l}\text { Wie wirksam sind Ihrer Meinung nach die } \\
\text { folgenden politischen Maßnahmen zur } \\
\text { Bekämpfung der weiteren Verbreitung des } \\
\text { Coronavirus? Besuchsverbot für Krankenhäuser, } \\
\text { Pflege- und Altersheime } \\
\text { How effective are the following policies in } \\
\text { fighting the further spread of the coronavirus in } \\
\text { your opinion? Ban on visiting hospitals, nursing } \\
\text { homes and old people's homes }\end{array}$ & $\begin{array}{l}\text { Überhaupt nicht wirksam; Wenig wirksam; } \\
\text { Teils/ teils; Ziemlich wirksam; Sehr wirksam } \\
\text { Not effective at all; Not very effective; Partly; } \\
\text { Quite effective; Very effective }\end{array}$ & hzcy023a \\
\hline
\end{tabular}


Table A2: Survey items used in the analysis. (continued)

\begin{tabular}{|c|c|c|c|}
\hline Construct & Item text (German/English) & Value labels (German/English) & GESIS Panel variable \\
\hline $\begin{array}{l}\text { Effectiveness of } \\
\text { government measures }\end{array}$ & $\begin{array}{l}\text { Wie wirksam sind Ihrer Meinung nach die } \\
\text { folgenden politischen Maßnahmen zur } \\
\text { Bekämpfung der weiteren Verbreitung des } \\
\text { Coronavirus? Ausgangssperre für Personen ab } \\
70 \text { Jahren oder mit gesundheitlichen Problemen } \\
\text { (außer für grundlegende Einkäufe und dringende } \\
\text { medizinische Versorgung) } \\
\text { How effective are the following policies in } \\
\text { fighting the further spread of the coronavirus in } \\
\text { your opinion? Curfew for people over } 70 \text { or } \\
\text { people with health problems (except for basic } \\
\text { purchases and urgent medical care) }\end{array}$ & $\begin{array}{l}\text { Überhaupt nicht wirksam; Wenig wirksam; } \\
\text { Teils / teils; Ziemlich wirksam; Sehr wirksam } \\
\text { Not effective at all; Not very effective; Partly; } \\
\text { Quite effective; Very effective }\end{array}$ & hzcy024a \\
\hline $\begin{array}{l}\text { Effectiveness of } \\
\text { government measures }\end{array}$ & $\begin{array}{l}\text { Wie wirksam sind Ihrer Meinung nach die } \\
\text { folgenden politischen Maßnahmen zur } \\
\text { Bekämpfung der weiteren Verbreitung des } \\
\text { Coronavirus? Ausgangssperrefür jeden, der nicht } \\
\text { im Gesundheitsbereich oder anderen kritischen } \\
\text { Berufen arbeitet (außer für grundlegende } \\
\text { Einkäufe und dringende medizinische } \\
\text { Versorgung) } \\
\text { How effective are the following policies in } \\
\text { fighting the further spread of the coronavirus in } \\
\text { your opinion? Curfew for anyone not working in } \\
\text { the health sector or other critical professions } \\
\text { (except for basic purchases and urgent medical } \\
\text { care) }\end{array}$ & $\begin{array}{l}\text { Überhaupt nicht wirksam; Wenig wirksam; } \\
\text { Teils/ teils; Ziemlich wirksam; Sehr wirksam } \\
\text { Not effective at all; Not very effective; Partly; } \\
\text { Quite effective; Very effective }\end{array}$ & hzcy025a \\
\hline
\end{tabular}


Table A2: Survey items used in the analysis. (continued)

\begin{tabular}{|c|c|c|c|}
\hline Construct & Item text (German/English) & Value labels (German/English) & GESIS Panel variable \\
\hline \multirow[t]{2}{*}{ Trust in actors } & $\begin{array}{l}\text { Wie sehr vertrauen Sie den folgenden Personen } \\
\text { und Institutionen in Bezug auf den Umgang mit } \\
\text { dem Coronavirus? Ihrem Hausarzt/ Ihrer } \\
\text { Hausärztin }\end{array}$ & $\begin{array}{l}\text { Vertraue überhaupt nicht; Vertraue eher nicht; } \\
\text { Weder noch; Vertraue eher; Vertraue voll und } \\
\text { ganz; Kenne ich nicht }\end{array}$ & hzcy044a \\
\hline & $\begin{array}{l}\text { How much do you trust the following people and } \\
\text { institutions in dealing with the coronavirus? } \\
\text { Your physician }\end{array}$ & $\begin{array}{l}\text { Don't trust at all; Trust rather not; Neither nor; } \\
\text { Trust rather; Entirely trust; I don't know }\end{array}$ & \\
\hline \multirow[t]{2}{*}{ Trust in actors } & $\begin{array}{l}\text { Wie sehr vertrauen Sie den folgenden Personen } \\
\text { und Institutionen in Bezug auf den Umgang mit } \\
\text { dem Coronavirus? Lokale Gesundheitsbehörde }\end{array}$ & $\begin{array}{l}\text { Vertraue überhaupt nicht; Vertraue eher nicht; } \\
\text { Weder noch; Vertraue eher; Vertraue voll und } \\
\text { ganz; Kenne ich nicht }\end{array}$ & hzcy045a \\
\hline & $\begin{array}{l}\text { How much do you trust the following people and } \\
\text { institutions in dealing with the coronavirus? } \\
\text { Local health authority }\end{array}$ & $\begin{array}{l}\text { Don't trust at all; Trust rather not; Neither nor; } \\
\text { Trust rather; Entirely trust; I don't know }\end{array}$ & \\
\hline \multirow[t]{2}{*}{ Trust in actors } & $\begin{array}{l}\text { Wie sehr vertrauen Sie den folgenden Personen } \\
\text { und Institutionen in Bezug auf den Umgang mit } \\
\text { dem Coronavirus? Kommunale und städtische } \\
\text { Verwaltung }\end{array}$ & $\begin{array}{l}\text { Vertraue überhaupt nicht; Vertraue eher nicht; } \\
\text { Weder noch; Vertraue eher; Vertraue voll und } \\
\text { ganz; Kenne ich nicht }\end{array}$ & hzcy046a \\
\hline & $\begin{array}{l}\text { How much do you trust the following people and } \\
\text { institutions in dealing with the coronavirus? } \\
\text { Local and municipal administration }\end{array}$ & $\begin{array}{l}\text { Don't trust at all; Trust rather not; Neither nor; } \\
\text { Trust rather; Entirely trust; I don't know }\end{array}$ & \\
\hline \multirow[t]{2}{*}{ Trust in actors } & $\begin{array}{l}\text { Wie sehr vertrauen Sie den folgenden Personen } \\
\text { und Institutionen in Bezug auf den Umgang mit } \\
\text { dem Coronavirus? Robert Koch-Institut (RKI) }\end{array}$ & $\begin{array}{l}\text { Vertraue überhaupt nicht; Vertraue eher nicht; } \\
\text { Weder noch; Vertraue eher; Vertraue voll und } \\
\text { ganz; Kenne ich nicht }\end{array}$ & hzcy047a \\
\hline & $\begin{array}{l}\text { How much do you trust the following people and } \\
\text { institutions in dealing with the coronavirus? } \\
\text { Robert Koch-Institute (RKI) }\end{array}$ & $\begin{array}{l}\text { Don't trust at all; Trust rather not; Neither nor; } \\
\text { Trust rather; Entirely trust; I don't know }\end{array}$ & \\
\hline
\end{tabular}


Table A2: Survey items used in the analysis. (continued)

\begin{tabular}{|c|c|c|c|}
\hline Construct & Item text (German/English) & Value labels (German/English) & GESIS Panel variable \\
\hline \multirow[t]{2}{*}{ Trust in actors } & $\begin{array}{l}\text { Wie sehr vertrauen Sie den folgenden Personen } \\
\text { und Institutionen in Bezug auf den Umgang mit } \\
\text { dem Coronavirus? Bundesregierung }\end{array}$ & $\begin{array}{l}\text { Vertraue überhaupt nicht; Vertraue eher nicht; } \\
\text { Weder noch; Vertraue eher; Vertraue voll und } \\
\text { ganz; Kenne ich nicht }\end{array}$ & \multirow[t]{2}{*}{ hzcy048a } \\
\hline & $\begin{array}{l}\text { How much do you trust the following people and } \\
\text { institutions in dealing with the coronavirus? } \\
\text { Federal government }\end{array}$ & $\begin{array}{l}\text { Don't trust at all; Trust rather not; Neither nor; } \\
\text { Trust rather; Entirely trust; I don't know }\end{array}$ & \\
\hline \multirow[t]{2}{*}{ Trust in actors } & $\begin{array}{l}\text { Wie sehr vertrauen Sie den folgenden Personen } \\
\text { und Institutionen in Bezug auf den Umgang mit } \\
\text { dem Coronavirus? Bundeskanzlerin }\end{array}$ & $\begin{array}{l}\text { Vertraue überhaupt nicht; Vertraue eher nicht; } \\
\text { Weder noch; Vertraue eher; Vertraue voll und } \\
\text { ganz; Kenne ich nicht }\end{array}$ & \multirow[t]{2}{*}{ hzcy049a } \\
\hline & $\begin{array}{l}\text { How much do you trust the following people and } \\
\text { institutions in dealing with the coronavirus? } \\
\text { German chancellor }\end{array}$ & $\begin{array}{l}\text { Don't trust at all; Trust rather not; Neither nor; } \\
\text { Trust rather; Entirely trust; I don't know }\end{array}$ & \\
\hline \multirow[t]{2}{*}{ Trust in actors } & $\begin{array}{l}\text { Wie sehr vertrauen Sie den folgenden Personen } \\
\text { und Institutionen in Bezug auf den Umgang mit } \\
\text { dem Coronavirus? Gesundheitsministerium }\end{array}$ & $\begin{array}{l}\text { Vertraue überhaupt nicht; Vertraue eher nicht; } \\
\text { Weder noch; Vertraue eher; Vertraue voll und } \\
\text { ganz; Kenne ich nicht }\end{array}$ & \multirow[t]{2}{*}{ hzcy050a } \\
\hline & $\begin{array}{l}\text { How much do you trust the following people and } \\
\text { institutions in dealing with the coronavirus? } \\
\text { Ministry of health }\end{array}$ & $\begin{array}{l}\text { Don't trust at all; Trust rather not; Neither nor; } \\
\text { Trust rather; Entirely trust; I don't know }\end{array}$ & \\
\hline \multirow[t]{2}{*}{ Trust in actors } & $\begin{array}{l}\text { Wie sehr vertrauen Sie den folgenden Personen } \\
\text { und Institutionen in Bezug auf den Umgang mit } \\
\text { dem Coronavirus? Weltgesundheitsorganisation } \\
\text { (WHO) }\end{array}$ & $\begin{array}{l}\text { Vertraue überhaupt nicht; Vertraue eher nicht; } \\
\text { Weder noch; Vertraue eher; Vertraue voll und } \\
\text { ganz; Kenne ich nicht }\end{array}$ & \multirow[t]{2}{*}{ hzcy051a } \\
\hline & $\begin{array}{l}\text { How much do you trust the following people and } \\
\text { institutions in dealing with the coronavirus? } \\
\text { World Health Organization (WHO) }\end{array}$ & $\begin{array}{l}\text { Don't trust at all; Trust rather not; Neither nor; } \\
\text { Trust rather; Entirely trust; I don't know }\end{array}$ & \\
\hline
\end{tabular}


Table A2: Survey items used in the analysis. (continued)

\begin{tabular}{|c|c|c|c|}
\hline Construct & Item text (German/English) & Value labels (German/English) & GESIS Panel variable \\
\hline Trust in actors & $\begin{array}{l}\text { Wie sehr vertrauen Sie den folgenden Personen } \\
\text { und Institutionen in Bezug auf den Umgang mit } \\
\text { dem Coronavirus? Wissenschaftlern/ } \\
\text { Wissenschaftlerinnen } \\
\text { How much do you trust the following people and } \\
\text { institutions in dealing with the coronavirus? } \\
\text { Scientists }\end{array}$ & $\begin{array}{l}\text { Vertraue überhaupt nicht; Vertraue eher nicht; } \\
\text { Weder noch; Vertraue eher; Vertraue voll und } \\
\text { ganz; Kenne ich nicht } \\
\text { Don't trust at all; Trust rather not; Neither nor; } \\
\text { Trust rather; Entirely trust; I don't know }\end{array}$ & hzcy052a \\
\hline Measures taken & $\begin{array}{l}\text { Welche dieser Maßnahmen haben Sie in den } \\
\text { letzten sieben Tagen getroffen? Sie können } \\
\text { mehrere Antworten ankreuzen. Ich habe } \\
\text { bestimmte (belebte) Orte gemieden. } \\
\text { Which of these measures have you taken in the } \\
\text { last seven days? You can tick several answers. I } \\
\text { have avoided certain (busy) places. }\end{array}$ & $\begin{array}{l}\text { 0: Nicht genannt; 1: Genannt } \\
\text { 0: Not quoted; 1: Quoted }\end{array}$ & hzcy006a \\
\hline Measures taken & $\begin{array}{l}\text { Welche dieser Maßnahmen haben Sie in den } \\
\text { letzten sieben Tagen getroffen? Sie können } \\
\text { mehrere Antworten ankreuzen. Ich habe } \\
\text { Abstand zu anderen Personen gehalten } \\
\text { (mindestens 1,5 Meter). } \\
\text { Which of these measures have you taken in the } \\
\text { last seven days? You can tick several answers. I } \\
\text { have kept distance to other people (at least } 1.5 \\
\text { meters). }\end{array}$ & $\begin{array}{l}\text { 0: Nicht genannt; 1: Genannt } \\
\text { 0: Not quoted; 1: Quoted }\end{array}$ & hzcy007a \\
\hline Measures taken & $\begin{array}{l}\text { Welche dieser Maßnahmen haben Sie in den } \\
\text { letzten sieben Tagen getroffen? Sie können } \\
\text { mehrere Antworten ankreuzen. Ich habe meine } \\
\text { Schul- oder Arbeitssituation angepasst. } \\
\text { Which of these measures have you taken in the } \\
\text { last seven days? You can tick several answers. I } \\
\text { have adapted my school or work situation. }\end{array}$ & $\begin{array}{l}\text { 0: Nicht genannt; 1: Genannt } \\
\text { 0: Not quoted; 1: Quoted }\end{array}$ & hzcy008a \\
\hline
\end{tabular}


Table A2: Survey items used in the analysis. (continued)

\begin{tabular}{|c|c|c|c|}
\hline Construct & Item text (German/English) & Value labels (German/English) & GESIS Panel variable \\
\hline Measures taken & $\begin{array}{l}\text { Welche dieser Maßnahmen haben Sie in den } \\
\text { letzten sieben Tagen getroffen? Sie können } \\
\text { mehrere Antworten ankreuzen. Ich habe mich in } \\
\text { Quarantäne begeben, weil ich Symptome habe. } \\
\text { Which of these measures have you taken in the } \\
\text { last seven days? You can tick several answers. I } \\
\text { have quarantined myself because I have } \\
\text { symptoms. }\end{array}$ & $\begin{array}{l}\text { 0: Nicht genannt; 1: Genannt } \\
\text { 0: Not quoted; 1: Quoted }\end{array}$ & hzcy009a \\
\hline Measures taken & $\begin{array}{l}\text { Welche dieser Maßnahmen haben Sie in den } \\
\text { letzten sieben Tagen getroffen? Sie können } \\
\text { mehrere Antworten ankreuzen. Ich habe mich in } \\
\text { Quarantäne begeben, obwohl ich keine } \\
\text { Symptome habe. } \\
\text { Which of these measures have you taken in the } \\
\text { last seven days? You can tick several answers. I } \\
\text { have quarantined myself, although I have no } \\
\text { symptoms. }\end{array}$ & $\begin{array}{l}\text { 0: Nicht genannt; 1: Genannt } \\
\text { 0: Not quoted; 1: Quoted }\end{array}$ & hzcy010a \\
\hline Measures taken & $\begin{array}{l}\text { Welche dieser Maßnahmen haben Sie in den } \\
\text { letzten sieben Tagen getroffen? Sie können } \\
\text { mehrere Antworten ankreuzen. Ich habe mir } \\
\text { öfter und länger die Hände gewaschen. } \\
\text { Which of these measures have you taken in the } \\
\text { last seven days? You can tick several answers. I } \\
\text { washed my hands more often and longer. }\end{array}$ & $\begin{array}{l}\text { 0: Nicht genannt; 1: Genannt } \\
\text { 0: Not quoted; 1: Quoted }\end{array}$ & hzcy011a \\
\hline Measures taken & $\begin{array}{l}\text { Welche dieser Maßnahmen haben Sie in den } \\
\text { letzten sieben Tagen getroffen? Sie können } \\
\text { mehrere Antworten ankreuzen. Ich habe } \\
\text { Desinfektionsmittel genutzt. } \\
\text { Which of these measures have you taken in the } \\
\text { last seven days? You can tick several answers. I } \\
\text { used disinfectant. }\end{array}$ & $\begin{array}{l}\text { 0: Nicht genannt; 1: Genannt } \\
\text { 0: Not quoted; 1: Quoted }\end{array}$ & hzcy012a \\
\hline
\end{tabular}


Table A2: Survey items used in the analysis. (continued)

\begin{tabular}{|c|c|c|c|}
\hline Construct & Item text (German/English) & Value labels (German/English) & GESIS Panel variable \\
\hline Measures taken & $\begin{array}{l}\text { Welche dieser Maßnahmen haben Sie in den } \\
\text { letzten sieben Tagen getroffen? Sie können } \\
\text { mehrere Antworten ankreuzen. Ich habe meine } \\
\text { Wasser- und/oder Lebensmittelvorräte } \\
\text { aufgestockt. } \\
\text { Which of these measures have you taken in the } \\
\text { last seven days? You can tick several answers. I } \\
\text { have stocked up on my water and/or food } \\
\text { supplies. }\end{array}$ & $\begin{array}{l}\text { 0: Nicht genannt; 1: Genannt } \\
\text { 0: Not quoted; 1: Quoted }\end{array}$ & hzcy013a \\
\hline Measures taken & $\begin{array}{l}\text { Welche dieser Maßnahmen haben Sie in den } \\
\text { letzten sieben Tagen getroffen? Sie können } \\
\text { mehrere Antworten ankreuzen. Ich habe } \\
\text { persönliche Treffen und Kontakte reduziert. } \\
\text { Which of these measures have you taken in the } \\
\text { last seven days? You can tick several answers. I } \\
\text { have reduced personal meetings and contacts. }\end{array}$ & $\begin{array}{l}\text { 0: Nicht genannt; 1: Genannt } \\
\text { 0: Not quoted; 1: Quoted }\end{array}$ & hzcy014a \\
\hline Measures taken & $\begin{array}{l}\text { Welche dieser Maßnahmen haben Sie in den } \\
\text { letzten sieben Tagen getroffen? Sie können } \\
\text { mehrere Antworten ankreuzen. Ich habe } \\
\text { Gesichtsmasken/Mundschutz getragen. } \\
\text { Which of these measures have you taken in the } \\
\text { last seven days? You can tick several answers. I } \\
\text { was wearing face masks. }\end{array}$ & $\begin{array}{l}\text { 0: Nicht genannt; 1: Genannt } \\
\text { 0: Not quoted; 1: Quoted }\end{array}$ & hzcy015a \\
\hline Measures taken & $\begin{array}{l}\text { Welche dieser Maßnahmen haben Sie in den } \\
\text { letzten sieben Tagen getroffen? Sie können } \\
\text { mehrere Antworten ankreuzen. Sonstiges } \\
\text { Which of these measures have you taken in the } \\
\text { last seven days? You can tick several answers. } \\
\text { Other }\end{array}$ & $\begin{array}{l}\text { 0: Nicht genannt; 1: Genannt } \\
\text { 0: Not quoted; 1: Quoted }\end{array}$ & hzcy016a \\
\hline
\end{tabular}


Table A2: Survey items used in the analysis. (continued)

\begin{tabular}{|c|c|c|}
\hline Construct & Item text (German/English) & Value labels (German/English) \\
\hline $\begin{array}{l}\text { Political ideology } \\
\text { (left/right) }\end{array}$ & $\begin{array}{l}\text { In der Politik spricht man manchmal von } \\
\text { "links"und "rechts". Wo auf der Skala von } 0 \text { bis } \\
10 \text { würden Sie sich selbst einstufen, wenn 0für } \\
\text { "links"steht und } 10 \text { für "rechts"? } \\
\text { In politics people sometimes talk of "left"and } \\
\text { "right". Where would you place yourself on this } \\
\text { scale, where } 0 \text { means "left"and } 10 \text { means } \\
\text { "right"? }\end{array}$ & $\begin{array}{l}0 \text { Links; } 1 ; 2 ; 3 ; 4 ; 5 ; 6 ; 7 ; 8 ; 9 ; 10 \text { Rechts } \\
0 \text { Left; } 1 ; 2 ; 3 ; 4 ; 5 ; 6 ; 7 ; 8 ; 9 ; 10 \text { Right }\end{array}$ \\
\hline Political interest & $\begin{array}{l}\text { Wie stark interessieren Sie sich für Politik? } \\
\text { How interested are you in politics? }\end{array}$ & $\begin{array}{l}\text { Sehr stark; Stark; Mittel; Wenig; Überhaupt } \\
\text { nicht } \\
\text { Very strong; Strong; Moderately; Little; Not at } \\
\text { all }\end{array}$ \\
\hline $\begin{array}{l}\text { Satisfaction with } \\
\text { democracy }\end{array}$ & $\begin{array}{l}\text { Wie zufrieden sind Sie - alles in allem - mit der } \\
\text { Art und Weise, wie die Demokratie in } \\
\text { Deutschland funktioniert? } \\
\text { On the whole, how satisfied are you with the } \\
\text { way democracy works in Germany? }\end{array}$ & $\begin{array}{l}0 \text { Äußerst unzufrieden; } 1 ; 2 ; 3 ; 4 ; 5 ; 6 ; 7 ; 8 ; 9 ; 10 \\
\text { Äußerst zufrieden } \\
0 \text { Extremely dissatisfied; } 1 ; 2 ; 3 ; 4 ; 5 ; 6 ; 7 ; 8 ; 9 ; \\
10 \text { Extremely satisfied }\end{array}$ \\
\hline Voting intention & $\begin{array}{l}\text { Wenn am nächsten Sonntag Bundestagswahl } \\
\text { wäre, würden Sie dann zur Wahl gehen? } \\
\text { If next Sunday were federal election, would you } \\
\text { go to the polls? }\end{array}$ & $\begin{array}{l}\text { Nein, ich würde nicht wählen.; Ja, ich würde } \\
\text { wählen.; Ich bin nicht wahlberechtigt. } \\
\text { No, I would not vote; Yes, I would vote; I am } \\
\text { not entitled to vote }\end{array}$ \\
\hline Voting intention & $\begin{array}{l}\text { Welche Partei würden Sie wählen, wenn am } \\
\text { nächsten Sonntag Bundestagswahl wäre? } \\
\text { Which party would you vote for if federal } \\
\text { elections were held next Sunday? }\end{array}$ & $\begin{array}{l}\text { CDU/CSU; SPD; FDP; DIE LINKE; BÜNDNIS } \\
\text { 90/DIE GRÜNEN; Alternative für Deutschland } \\
\text { (AfD); Andere Partei, und zwar:; Ich bin nicht } \\
\text { wahlberechtigt.; Weiß ich nicht. } \\
\text { CDU/CSU; SPD; FDP; DIE LINKE; BÜNDNIS } \\
\text { 90/DIE GRÜNEN; Alternative für Deutschland } \\
\text { (AfD); Other party, and that is:; I am not } \\
\text { entitled to vote; I don't know }\end{array}$ \\
\hline
\end{tabular}
GESIS Panel variable

gbzc064a

gbzc001a

gbzc063a

gbzc012a 
Table A2: Survey items used in the analysis. (continued)

\begin{tabular}{|c|c|c|c|}
\hline Construct & Item text (German/English) & Value labels (German/English) & GESIS Panel variable \\
\hline Education & $\begin{array}{l}\text { Zunächst zu Ihrer Schulbildung: Welchen } \\
\text { höchsten allgemeinbildenden Schulabschluss } \\
\text { haben Sie? } \\
\text { Concerning your general education: What is } \\
\text { your highest general degree of education? }\end{array}$ & $\begin{array}{l}\text { Schüler/-in; Von der Schule abgegangen ohne } \\
\text { Abschluss; Abschluss nach höchstens } 7 \text { Jahren } \\
\text { Schulbesuch (im Ausland); Polytechnische } \\
\text { Oberschule DDR, Abschluss 8. oder 9. Klasse; } \\
\text { Polytechnische Oberschule DDR, Abschluss 10. } \\
\text { Klasse; Hauptschulabschluss, } \\
\text { Volksschulabschluss; Realschulabschluss, } \\
\text { Mittlere Reife; Fachhochschulreife; Abitur, } \\
\text { allgemeine oder fachgebundene Hochschulreife } \\
\text { Student; Left school without degree; Degree } \\
\text { after } 7 \text { years of school attendance at most } \\
\text { (abroad); Polytechnic secondary school GDR, } \\
\text { Degree 8th or 9th grade; Polytechnic secondary } \\
\text { school GDR, Degree 10th grade; Lower } \\
\text { secondary school; Secondary school; Advanced } \\
\text { technical college certificate; General qualification } \\
\text { for university entrance }\end{array}$ & gfzh038a \\
\hline Household size & $\begin{array}{l}\text { Wie viele Personen leben ständig in Ihrem } \\
\text { Haushalt, Sie selbst eingeschlossen? } \\
\text { How many people, you included, regularly live in } \\
\text { your household? }\end{array}$ & $\begin{array}{l}\text { Eine Person (ich); Mehr als eine Person } \\
\text { One person (myself); More than one person }\end{array}$ & ffzh045a \\
\hline Age & $\begin{array}{l}\text { Wann sind Sie geboren? Bitte nennen Sie mir } \\
\text { Monat und Jahr Ihrer Geburt; Geben Sie uns } \\
\text { bitte an, in welchem Monat und in welchem } \\
\text { Jahr Sie geboren sind. } \\
\text { When were you born? Please tell me the month } \\
\text { and the year; Please tell us what month and } \\
\text { year you were born in. }\end{array}$ & $\begin{array}{l}\text { Jahr und Monat } \\
\text { Year and month }\end{array}$ & $\begin{array}{l}\text { please see respective } \\
\text { datasets }\end{array}$ \\
\hline Gender & $\begin{array}{l}\text { Sind Sie männlich oder weiblich? } \\
\text { Are you male or female? }\end{array}$ & $\begin{array}{l}\text { 1: Männlich, 2: Weiblich } \\
\text { 1: Male, 2: female }\end{array}$ & $\begin{array}{l}\text { please see respective } \\
\text { datasets }\end{array}$ \\
\hline
\end{tabular}

Note:

Data from the GESIS Panel Special Survey on the Coronavirus SARS-CoV-2 Outbreak in Germany (GESIS Panel Team 2020), the GESIS Panel

Standard Edition (GESIS 2020b) and the GESIS Panel Extended Edition (GESIS 2020a). 


\section{Descriptive statistics}

Table A3: Descriptive statistics.

\begin{tabular}{lcccccc}
\hline \hline Statistic & $\mathrm{N}$ & Mean & St. Dev. & Min & Median & Max \\
\hline Perceived risk of infection & 3,183 & 50.51 & 17.22 & 0.00 & 50.00 & 100.00 \\
Perceived effectiveness of measures & 3,179 & 79.12 & 16.88 & 0.00 & 79.17 & 100.00 \\
Trust in actors & 3,160 & 72.57 & 17.15 & 0.00 & 75.00 & 100.00 \\
Measures taken & 3,186 & 49.99 & 16.08 & 0.00 & 50.00 & 100.00 \\
COVID-19 information exposure & 3,169 & 3.89 & 1.57 & 0.00 & 4.00 & 10.00 \\
Public broadcasting & 3,169 & 0.92 & 0.27 & 0.00 & 1.00 & 1.00 \\
Commercial broadcasting & 3,169 & 0.45 & 0.50 & 0.00 & 0.00 & 1.00 \\
Newspapers & 3,169 & 0.67 & 0.47 & 0.00 & 1.00 & 1.00 \\
Social media & 3,169 & 0.27 & 0.45 & 0.00 & 0.00 & 1.00 \\
Facebook & 3,169 & 0.19 & 0.39 & 0.00 & 0.00 & 1.00 \\
Personal conversations & 3,169 & 0.56 & 0.50 & 0.00 & 1.00 & 1.00 \\
Political ideology (left/right) & 3,184 & 4.65 & 1.87 & 0.00 & 5.00 & 10.00 \\
Political interest & 3,141 & 3.28 & 0.89 & 1.00 & 3.00 & 5.00 \\
Satisfaction with democracy & 3,132 & 6.08 & 2.30 & 0.00 & 7.00 & 10.00 \\
AfD & 3,037 & 0.08 & 0.27 & 0.00 & 0.00 & 1.00 \\
CDU/CSU & 3,037 & 0.22 & 0.41 & 0.00 & 0.00 & 1.00 \\
Linke & 3,037 & 0.09 & 0.28 & 0.00 & 0.00 & 1.00 \\
FDP & 3,037 & 0.07 & 0.26 & 0.00 & 0.00 & 1.00 \\
Grüne & 3,037 & 0.23 & 0.42 & 0.00 & 0.00 & 1.00 \\
SPD & 3,037 & 0.11 & 0.31 & 0.00 & 0.00 & 1.00 \\
Other party or don't know & 3,037 & 0.21 & 0.41 & 0.00 & 0.00 & 1.00 \\
Household: 1 person & 3,238 & 0.11 & 0.32 & 0 & 0 & 1 \\
Household: 2 persons & 3,238 & 0.48 & 0.50 & 0 & 0 & 1 \\
Household: 3+ persons & 3,238 & 0.40 & 0.49 & 0 & 0 & 1 \\
Age & 3,238 & 52.42 & 14.01 & 23 & 54 & 75 \\
Female & 3,238 & 0.49 & 0.50 & 0 & 0 & 1 \\
Low education & 3,237 & 0.11 & 0.31 & 0.00 & 0.00 & 1.00 \\
Medium education & 3,237 & 0.31 & 0.46 & 0.00 & 0.00 & 1.00 \\
High education & 3,237 & 0.58 & 0.49 & 0.00 & 1.00 & 1.00 \\
\hline
\end{tabular}




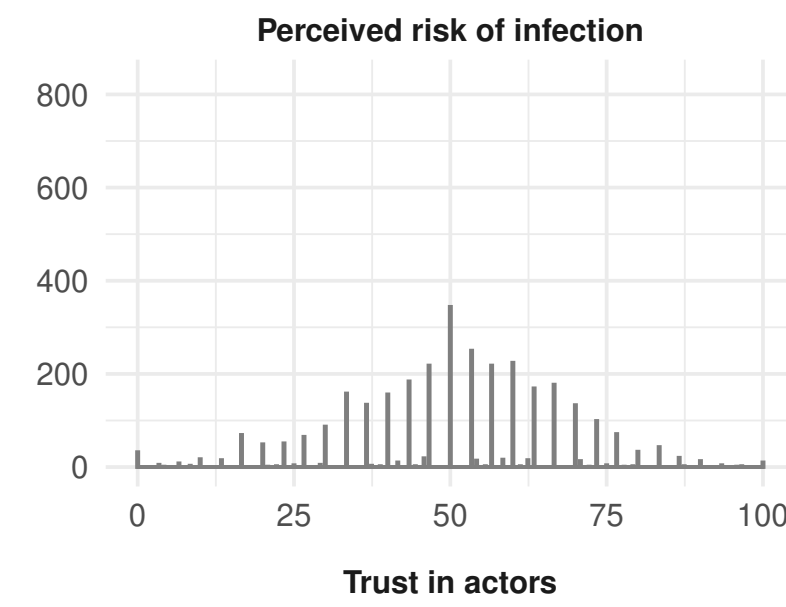

Perceived effectiveness of measures
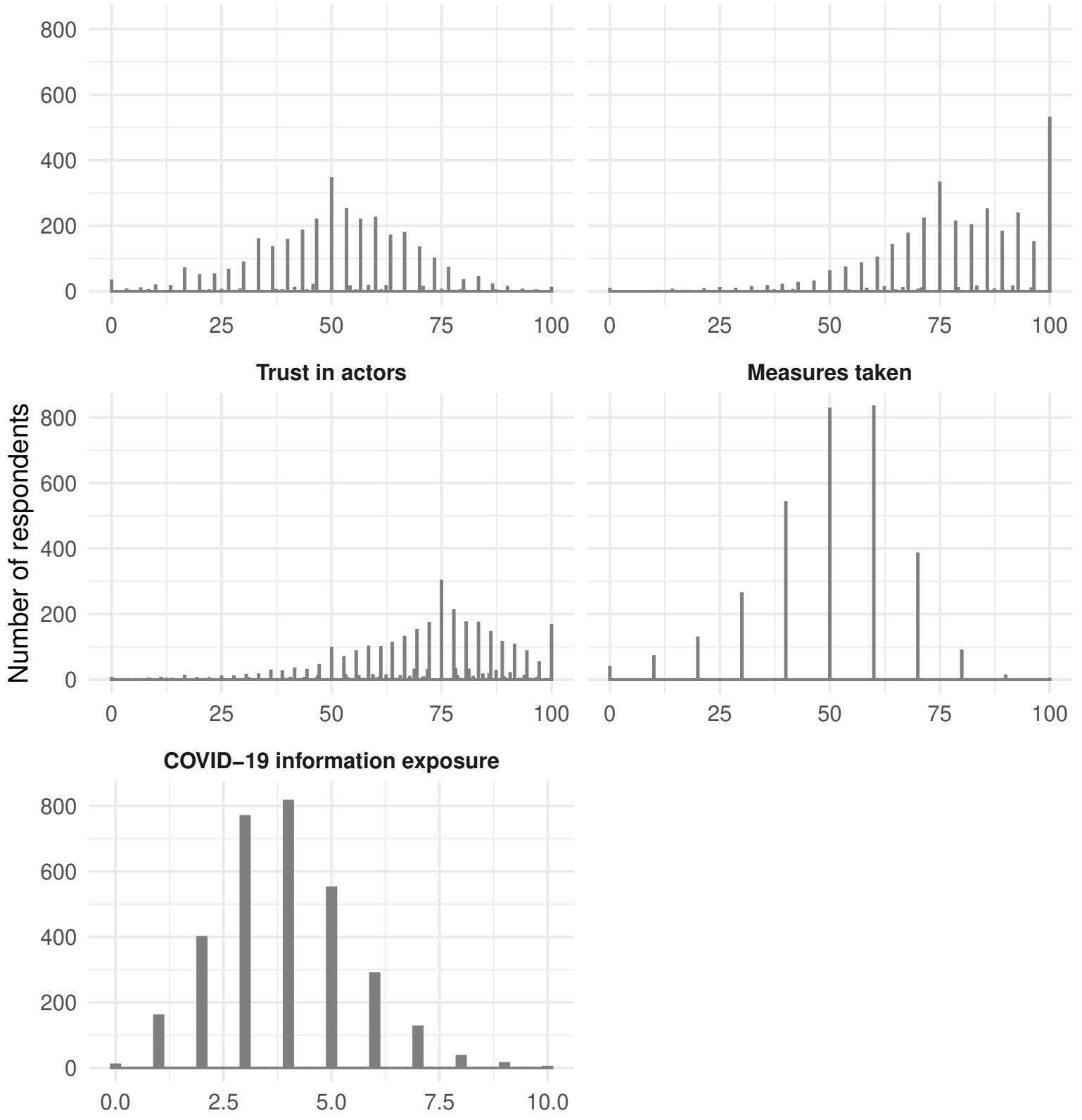

Figure A1: Distribution of the four outcome variables and the main independent variable. 


\section{Additional details on the text analysis}

Table A4: Top 40 German Facebook pages ranked by the number of interactions their COVID-19 related posts received.

\begin{tabular}{|c|c|c|}
\hline Page name & Total interactions & Information source \\
\hline Bild & $1,534,398$ & National newspapers \\
\hline tagesschau & $1,489,395$ & National public broadcasting \\
\hline Der Postillon & $1,378,328$ & Other sources \\
\hline DER SPIEGEL & $1,278,872$ & National newspapers \\
\hline Zeit im Bild & $1,184,934$ & Other sources \\
\hline ZDF heute & $1,135,288$ & National public broadcasting \\
\hline Oliver Pocher & $1,134,471$ & Other sources \\
\hline RTL Aktuell & $1,107,141$ & National private broadcasting \\
\hline FOCUS Online & $1,036,285$ & National newspapers \\
\hline Corona Virus - Liveticker & 656,654 & Other sources \\
\hline Bundesregierung & 596,641 & Other sources \\
\hline ntv Nachrichten & 575,541 & National private broadcasting \\
\hline Punkt 12 & 570,533 & National private broadcasting \\
\hline WELT & 522,862 & National newspapers \\
\hline Alice Weidel & 516,336 & Other sources \\
\hline Notruf & 498,760 & Other sources \\
\hline stern & 454,046 & National newspapers \\
\hline RT Deutsch & 439,316 & Other sources \\
\hline Sebastian Kurz & 435,008 & Other sources \\
\hline RTL.de & 411,111 & National private broadcasting \\
\hline WELT Nachrichtensender & 396,964 & National private broadcasting \\
\hline Newsner Deutsch & 377,395 & Other sources \\
\hline BILD News & 354,927 & National newspapers \\
\hline Kronen Zeitung & 337,246 & Other sources \\
\hline Rammstein & 321,782 & Other sources \\
\hline Bundesministerium für Gesundheit & 313,067 & Other sources \\
\hline oe24.at & 305,490 & Other sources \\
\hline Politik und Zeitgeschehen & 305,043 & Other sources \\
\hline Prof. Dr. Jörg Meuthen & 296,632 & Other sources \\
\hline WEB.DE News & 292,604 & Other sources \\
\hline $\mathrm{BR} 24$ & 291,537 & Local public broadcasting \\
\hline ZEIT ONLINE & 284,884 & National newspapers \\
\hline Addnfahrer & 276,339 & Other sources \\
\hline Best Trend Videos & 268,745 & Other sources \\
\hline ANTENNE BAYERN & 264,386 & Local public broadcasting \\
\hline Lidl Deutschland & 257,977 & Other sources \\
\hline $\mathrm{AfD}$ & 246,927 & Other sources \\
\hline SWR Aktuell & 236,407 & Local public broadcasting \\
\hline BUNTE.de & 236,143 & National newspapers \\
\hline Promiflash & 224,462 & Other sources \\
\hline
\end{tabular}


Table A5: Ten example posts for each topic, randomly sampled from documents with topic probability $>0.7$.

\begin{tabular}{|c|c|}
\hline Topic & Example posts \\
\hline \multirow{15}{*}{$\begin{array}{l}\text { Early outbreak } \\
\& \text { uncertainty }\end{array}$} & Reine Vorsicht oder völlig irre? \\
\hline & $\begin{array}{l}\text { Ist der Coronavirus wirklich gefährlicher als eine normale Grippe? Oder ist alles halb } \\
\text { so wild? Ein objektiver Faktencheck. StN Plus }\end{array}$ \\
\hline & $\begin{array}{l}\text { In einer chinesischen klinischen Studie erwies sich der Wirkstoff als wirksam gegen } \\
\text { SARS-CoV-2! }\end{array}$ \\
\hline & Oder macht das etwa keinen Unterschied? \\
\hline & $\begin{array}{l}\text { Die Gefahr, die von der Verbreitung des Coronavirus ausgeht, wird zunehmend ernst } \\
\text { genommen: }\end{array}$ \\
\hline & $\begin{array}{l}\text { Wie man eine Infektion erkennt, wie man sich schützen kann und wer besonders } \\
\text { gefährdet ist. }\end{array}$ \\
\hline & $\begin{array}{l}\text { Es gibt auch schon Menschen, die sich die Post-Corona-Zeit ausmalen, Der } \\
\text { Zukunftsforscher Matthias Horx hat nun ein ungemein optimistisches Szenario } \\
\text { entworfen. }\end{array}$ \\
\hline & $\begin{array}{l}\text { Coronavirus - Aussagen eines italienischen Krankenpflegers untermauern eine extrem } \\
\text { schwierige und gefährliche Situation die entstanden ist }\end{array}$ \\
\hline & $\begin{array}{l}\text { Im Vergleich mit der Grippe wurde das Coronavirus als harmloser dargestellt, nach } \\
\text { neuen Erkenntnissen stimmt das nicht. }\end{array}$ \\
\hline & $\begin{array}{l}\text { Viele haben Angst, das Coronavirus könnte sich auf der ganzen Welt ausbreiten und } \\
\text { so zu einer Pandemie werden. So weit ist es zum Glück noch nicht. }\end{array}$ \\
\hline & $\begin{array}{l}\text { Die Polizei des Landes Sachsen-Anhalt wird am Wochenende verstärkt im Einsatz } \\
\text { sein. Es wird Aufklärungsgespräche, zusätzliche Kontrollen und Streifen geben, um } \\
\text { sicherzustellen, dass die Maßgaben zum Schutz vor Corona eingehalten werden. }\end{array}$ \\
\hline & $\begin{array}{l}\text { \#Corona: Weitere Maßnahmen zur Eindämmung der Corona-Virus-Pandemie in } \\
\text { \#NRW beschlossen: Keine Freizeit-, Sport-, Unterhaltungs- und Bildungsangebote \& } \\
\text { Schließung von „Amüsierbetrieben“ \& Auflagen für Einkaufszentren. Alle Details: } \\
\text { https://www.land.nrw/de/pressemitteilung/landesregierung-beschliesst-weitere- } \\
\text { massnahmen-zur-eindaemmung-der-corona-virus }\end{array}$ \\
\hline & $\begin{array}{l}\text { Ab Montag fällt in Oberhausen der Unterricht aus. Auch die Kitas müssen wegen } \\
\text { Corona schließen. Für bestimmte Berufe gibt es eine Notbetreuung. }\end{array}$ \\
\hline & Das Rhein-Gymnasium in Köln-Mülheim bleibt zunächst einen Tag geschlossen. \\
\hline & +++ Das teilt die Landesregierung mit. +++ \\
\hline
\end{tabular}


Government measures
Corona-Update 2 - 25.3. Regelmäßige Magistratssitzungen via Telefonkonferenz Haushalt könnte im Haupt- und Finanzausschuss beschlossen werden

-Auch in Hanau hat die allgemeine Infektionslage nach dem Ausbruch des Corona-Virus dazu geführt, dass seit Mitte des Monats alle Gremiensitzungen vorläufig abgesagt sind. Um dennoch politisch handlungsfähig zu bleiben, wird der Magistrat ab sofort in regelmäßigen Telefonkonferenzen die Vorlagen beraten. Notwendige Beschlüsse werden anschließend im Umlaufverfahren gefasst. Dies hat Oberbürgermeister Claus Kaminsky seinen Magistratskollegen am Dienstag in der erstmaligen Zusammenkunft dieser Art mitgeteilt. Darüber hinaus informierte der OB sie über die Möglichkeiten, die das „Gesetz zur Sicherung der kommunalen Entscheidungsfähigkeit", das vom Hessischen Landtag am Montag verabschiedet wurde, für die Stadt eröffnet. Unaufschiebbare Beschlüsse können demnach in hessischen Kommunen ab sofort an den Haupt- und Finanzausschuss (HFA) delegiert werden. Wie der OB dem Magistrat berichtet hat, will er dieses Vorgehen in einer Telefonkonferenz mit der Stadtverordnetenvorsteherin Beate Funck sowie dem Präsidium, den Ortsvorstehern und der Vorsitzenden des Ausländerbeirats, Selma Yilmaz-Ilkhan, abstimmen. Der HFA könnte dann in naher Zukunft auch über den Doppelhaushalt 2020/21 entscheiden. Beschlossen wurde im Hessischen Landtag nach den Worten des OB auch die Ergänzung der Hessischen Gemeindeordnung, die künftig in § 149 regelt, dass Kommunen ab 100.000 Einwohner die Kreisfreiheit anstreben können, dass dieser Passus aber explizit nicht für Hanau angewendet wird. \#coronavirus \#magistrat \#stadtverordnetenversammlung \#hanau \#clauskaminsky

„Ab Montag müssen wir unser soziales Leben auf ein Minimum reduzieren.” Kanzler Sebastian Kurz (ÖVP) verkündet weitreichende Maßnahmen gegen die Verbreitung des Coronavirus. Ab Montag sind fast alle Geschäfte geschlossen, die Gastronomie wird stark eingeschränkt. Das Paznauntal und St. Anton am Arlberg in Tirol sind unter Quarantäne gestellt:

Gottesdienste finden ohne die Gemeinde statt.

Nicht nur die Schulen und Kitas werden in den Niederlanden geschlossen.

Schulen und Kitas geschlossen: Wie wirkt sich das auf das öffentliche Leben in Bremen aus? Ein Streifzug durch eine Stadt.

Patienten dürfen wegen der Corona-Krise von Vertragsärzten ab sofort statt sieben bis zu 14 Tage am Telefon krankgeschrieben werden.

Fieber? Husten, Atemnot? Gliederschmerzen? Könnte es Corona sein? Was tun?|fs

Die professionellen Masken gibt es in drei Schutzklassen. \#Coronavirus

Feuerwehr und Krankenhäuser wurden in Corona-Krise bereits beliefert.

Das Caritas-Pirckheimer-Haus bietet seine Räume für Ärzte und Pflegepersonal an.

Neben Türklinken und Lichtschaltern gibt es viele weitere Gegenstände, die wir regelmäßig berühren, aber eventuell nur selten säubern

Dadurch soll das medizinische Versorgungssystem entlastet werden.

Das Ansteckungsrisiko soll verringert werden.

Natürlich werden für Therapien und Notfälle auch jetzt Blutpräparate gebraucht.

Freiwillige Helfer in der Not.

Die Auswirkungen des Coronavirus auf die Weltwirtschaft und die Kapitalmärkte sind massiv. 
Bisher hat vor allem die in der Rezession steckende Industrie das Barometer gedrückt. Nun ist es der Arbeitsmarkt. Auswirkungen der Corona-Epidemie seien das noch nicht.

Das Geld soll gestaffelt ausgezahlt werden.

Den Corona-gebeutelten Reisebüros geht es doppelt an die Finanzen. Anbieter wie Tui, FTI oder DER Touristik fordern Provisionen in dreistelliger Millionenhöhe zurück.

Bei den Arbeitgebern gibt es erste Forderungen an die Gewerkschaften, wegen der Corona-Krise Zugeständnisse bei den Lohnforderungen zu machen. Aber IG-Metall-Chef Hofmann sagt: "Mit der IG Metall gibt es keinen Corona-Abschluss."

Impact on economy

Die Verkaufszahlen brechen ein.

Der Bund kann seine Corona-Schulden nicht durch neue Kredite refinanzieren, sondern muss sie tilgen.

Das Hilfspaket soll arbeitslosen Arbeitnehmern und Industrien, die von der Coronavirus-Pandemie betroffen sind, unter die Arme greifen.

Je nach Szenario schrumpfe die deutsche Wirtschaft um 7,2 bis 20,6 Prozentpunkte. Das entspricht Kosten in Höhe von 255 bis 729 Milliarden Euro.

+++ „Die Kosten werden voraussichtlich alles übersteigen, was aus Wirtschaftskrisen oder Naturkatastrophen der letzten Jahrzehnte in Deutschland bekannt ist", sagt Ifo-Präsident Clemens Fuest. +++

In der Nacht auf heute ist eine dritte Person in Österreich am Coronavirus verstorben. Es handelt sich um eine 76-jährige Steirerin, die an Vorerkrankungen litt:

Die Zahl der Corona-Fälle in Hessen ist über das Wochenende auf insgesamt zehn angestiegen. Die Behörden meldeten am Sonntagabend zwei weitere betroffene Personen. Der Mann und die Frau sowie ihr engerer Kontaktkreis sind nun in häuslicher Quarantäne.

Das Virus hat nun auch den Kreis Ludwigsburg erreicht.

Immer mehr Menschen werden positiv getestet

Entwarnung auch beim 3. Coronavirus-Verdachtsfall in Niederösterreich! Local \&
personal stories

Dem 68-Jährigen aus der Region Hannover gehe es gut - Personen, mit denen er in Kontakt stand, sind nun unter Quarantäne.

Ein Mann in Bayern ist mit dem Virus infiziert.

Die Zahl der bestätigten Corona-Infektionen in Sachsen-Anhalt steigt weiter. Mit Stand 11 Uhr sind bisher 24 Infektionen gemeldet worden, damit sind seit gestern Abend zehn neue Fälle hinzugekommen.

Erstmals ist eine Infektion mit dem Coronavirus in Deutschland bestätigt worden. Ein Mann in Bayern hat sich infiziert. Wo und wie er sich angesteckt hat, ist noch nicht bekannt. 
Die gemeinsam tagenden Krisenstäbe der Stadt Aachen und der StädteRegion Aachen haben sich am Sonntagmorgen getroffen, um die aktuelle Lage in Sachen Corona-Virus zu besprechen. Dabei wurde festgehalten, dass es insgesamt in der StädteRegion nunmehr 57 Fälle gibt, davon 20 in der Stadt Aachen. Schulen und Kita: Acht Schulen in der StädteRegion und eine Kita mit einem positiven Corona-Fall bleiben noch bis 15. März geschlossen. Im Überblick sind das: · Maria-Sibylla-Merian-Gesamtschule (Herzogenrath) · Paul-Julius-Reuter Berufskolleg (Aachen) · Regenbogenschule (Stolberg) · Grundschule Grengracht (Baesweiler) · Heilig-Geist-Gymnasium (Würselen) · Gymnasium Baesweiler · Berufskolleg Herzogenrath · Berufskolleg Simmerath/Stolberg !nur Standort Stolberg! · Kita Biberburg (Alsdorf) In all diesen Fällen ist der Krankheitsverlauf mild oder moderat. Die betroffenen Personen befinden sich derzeit in häuslicher Quarantäne. Alle Anordnungen wurden aus Gründen des vorsorglichen...

Aktuelle Lage Stadt und StädteRegion Aachen zum Corona-Virus (Stand: 05.03.20, 12 Uhr) - Aktuell 33 bestätigte Corona-Fälle in der StädteRegion Aachen (davon zehn in der Stadt Aachen). - Das Heilig-Geist-Gymnasium in Würselen ist nach bestätigtem Coronafall geschlossen worden. Die Krisenstäbe geben am Freitagnachmittag bekannt, wie weiter mit den bislang geschlossenen Einrichtungen verfahren wird. - Kommunales Abstrichzentrum ist gut angelaufen. 300 Anrufe am ersten Tag, 100 Bürgerinnen und Bürger haben bereits einen Termin erhalten. Die gemeinsam tagenden Krisenstäbe der Stadt Aachen und der StädteRegion Aachen haben sich am Donnerstagmorgen getroffen, um die aktuelle Lage in Sachen Corona-Virus zu besprechen. Dabei wurde festgehalten, dass es insgesamt in der StädteRegion nunmehr 33 Fälle gibt, davon zehn in der Stadt Aachen, 22 Fälle in den übrigen neun Kommunen der StädteRegion, ein Fall konnte bislang nicht zugeordnet werden. Schulen: Die Krisenstäbe werden am morgigen...

Das vermeldet die Stadt.

Wenn Aachens Oberbürgermeister Marcel Philipp neue kommunale Einrichtungen eröffnet, dann ist das normalerweise ein Grund zur Freude. Von Freude kann beim neuen kommunalen Abstrichzentrum der Stadt und der Städteregion, das am Tivoli eröffnet worden ist, keine Rede sein. Dass es da ist, ist trotzdem gut. $[+]$ \#Coronavirus | \#Corona | \#Coronakrise | \#Covid19 | \#Aachen | \#Tivoli | \#Abstrichzentrum | \#Städteregion

Aktuelle Lage Stadt und StädteRegion Aachen zum Corona-Virus; Dienstag, 3.3., 12.15 Uhr Aktuell 13 bestätigte Corona-Fälle in der StädteRegion Aachen (davon fünf in der Stadt Aachen). Diese Schulen sind bis mindestens zum 8. März geschlossen: Paul-Julius-Reuter-Berufskolleg in Aachen, Regenbogenschule in Stolberg, Maria-Sybilla-Merian-Gesamtschule in Herzogenrath, Grundschule Grengracht in Baesweiler. Der Standort Beggendorf ist nicht betroffen. Corona-Info-Hotline 0241/510051, täglich von 7 bis 21 Uhr geschaltet ist. Die gemeinsam tagenden Krisenstäbe der Stadt Aachen und der StädteRegion Aachen haben sich am Dienstagmorgen getroffen, um die aktuelle Lage in Sachen Corona-Virus zu besprechen. Dabei wurde festgehalten, dass es in der Stadt Aachen nunmehr in Summe fünf Fälle und in der StädteRegion acht Fälle gibt. Vor diesem Hintergrund sind aus Sicht der Krisenstäbe derzeit keine weiteren Schulschließungen bis auf die Schulen, in denen positive Fälle nachgewiesen sind, derzeit... 
Schließung des Weiterbildungskollegs wegen eines bestätigten Coronafalls. Betroffen sind die Standorte in Würselen und Aachen StädteRegion - Ein Mitarbeiter des Weiterbildungskollegs der StädteRegion Aachen wurde jetzt positiv auf das Coronavirus getestet. Der Mitarbeiter war an beiden Standorten tätig (Würselen, Friedrichstr. 72 und Aachen, Eintrachtstr. 3). Die StädteRegion Aachen als Schulträger hat entschieden, dass das Weiterbildungskollegs aus diesem Grund mindestens bis 15. März vorsorglich geschlossen wird. Zehn Schulen in der StädteRegion und eine Kita bleiben noch bis 15. März geschlossen. Im Überblick sind das: · Maria-Sibylla-Merian-Gesamtschule (Herzogenrath) · Paul-Julius-Reuter Berufskolleg (Aachen) · Regenbogenschule (Stolberg) · Grundschule Grengracht (Baesweiler) · Heilig-Geist-Gymnasium (Würselen) · Gymnasium Baesweiler · Berufskolleg Herzogenrath · Berufskolleg Simmerath/Stolberg !nur Standort Stolberg! · Pharmazeutisch-Technische Lehranstalt Baesweiler ....

Aktuelle Lage Stadt und StädteRegion Aachen zum Corona-Virus; Mittwoch, 25.03., 10.45 Uhr, Aktuell 618 bestätigte Coronafälle in der StädteRegion Aachen (davon 315 in der Stadt Aachen). Ein achter Todesfall. Krisenstäbe richten zweites Abstrichzentrum im Tivoli in Aachen ein, das morgen an den Start geht. Es gelten die Kontakte: E-Mail an KAZ-Leitung@staedteregion-aachen.de; Telefonhotline 0241/5198-7500. Karlspreis-Verleihung inklusive des Rahmenprogramms und des Jugendkarlspreises wird verschoben. Die gemeinsam tagenden Krisenstäbe der Stadt Aachen und der StädteRegion Aachen haben sich am Mittwochmorgen erneut getroffen, um die aktuelle Lage in Sachen Corona-Virus zu besprechen. Dabei wurde festgehalten, dass es insgesamt in der StädteRegion nunmehr 618 positive Fälle gibt, davon 315 in der Stadt Aachen Es gibt einen weiteren Todesfall in einem städteregionalen Krankenhaus zu vermelden: Ein 1954 geborener Mann aus Aachen ist gestorben. Somit erhöht sich die Zahl der...

Local

information Das sagt Philipp Achammer.

West Germany

Vielen Dank an all diejenigen, die heute zu Hause geblieben sind und uns auf diese Weise im Kampf gegen den \#Corona-Virus unterstützt haben.

Wir merken durch die zahlreichen Kommentare, dass es noch immer viele Fragen und Unsicherheiten bei euch gibt. Auch morgen werden wir euch wieder mit Informationen zur Seite stehen.

Doch für heute ist vorerst Schluss. Nach 15 Stunden Kommentar-Marathon melden wir uns für heute ab. Gute Nacht und \#StayatHome FAQs:

https://www.corona-katastrophenschutz.bayern.de/faq/index.php

Wegen der Corona-Krise wurden nun erste Planänderungen getroffen!

Michael Wendler und seine Laura. Die beiden gibt's nur noch im Doppelpack. Auch das Coronavirus kann die beiden nicht entzweien.

Claudia Krogul hatte eine Lungen-Transplantation. Für die Nordkirchenerin ist die Corona-Gefahr besonders groß. Sie sagt: „Ich bin die, die an ein Atemgerät muss.“

Heute um 20:15 Uhr startet das neue Talk-Format bei ntv: \#timeline. In der ersten Ausgabe spricht Moderator Micky Beisenherz mit dem stellvertretenden SPD-Chef Kevin Kühnert und Moderatorin und Kolumnistin Laura Karasek. Sie thematisieren unter anderem das Tempolimit auf deutschen Autobahnen und das Coronavirus. Die Sendung könnt ihr außerdem bei tvnow.de sehen.

Ein Gespräch mit dem Kinderarzt Dr. Ralf van Heek.

Linda Zervakis : Ehrliche Quarantäne-Berichterstattung der "Tagesschau"-Sprecherin

Der Experte hat einige Praxistipps

13 Uhr Pressekonferenz zum Corona-Virus Live bei Hallelife 
Oliver Pocher: Er kann Amira nicht mehr riechen

Heute Abend um 19:30 Uhr live: Psychiater und Stressforscher Prof. Dr. Mazda Adli spricht über die psychologischen Aspekte der Corona-Epidemie und beantwortet Ihre Fragen.

+++ Pressekonferenz jetzt live! +++

"Das ist unprofessionell - und offenbart, wie unfähig die große Koalition beim Krisenmanagement ist."

Jetzt Live Das sagt die FPÖ zum Coronavirus.

https://social.vol.at/ICV:=:https://www.vol.at/live-ab-9-30-uhr-das-sagt-die-fpoezum-coronavirus $/ 6568031$ ?Tool=Falcon\&Facebook=facebook

Kanzlerin Angela Merkel (CDU) spricht zur Corona-Krise:

http://szo.de/?arid=11201822:=:https://www.schwaebische.de/ueberregional/politik_artikel,merkel-in-fernsehansprache-es-ist-ernst-nehmen-sie-es-auch-ernst-_arid,11201822.html

Live: Merkel nach der Ministerpräsidentenkonferenz zur Corona-Krise.

Beim Parteitag sollte eigentlich der Nachfolger von Annegret Kramp-Karrenbauer als Parteichef gewählt werden.

National political actors

Ausnahmsweise haben alle sechs Fraktionen einmündig zugestimmt!

Merkels Rede an die Nation! Die Kanzlerin zur Corona-Krise

"Riesenarbeit für die Sicherheitsbehörden":

LIVE: Coronavirus - Merkel gibt Pressekonferenz nach Konsultation mit

EU-Regierungschefs Bundeskanzlerin Angela Merkel gibt im Anschluss nach einer

Videokonferenz mit Staats- und Regierungschefs der Europäischen Union zu

Maßnahmen im Umgang mit dem Coronavirus eine Pressekonferenz.

EU-Kommissions-Chefin Ursula von der Leyen ruft Mitgliedsländer zu mehr Solidarität auf.

Der Chemnitzer PSV hat wegen der Coronakrise die Notbremse gezogen und die 41. Auflage der Erzgebirgsrundfahrt abgesagt. Der Rad-Klassiker sollte am 10. Mai 2020 mit Start und Ziel vor dem Brauhaus Einsiedel wieder als Bundesligarennen ausgetragen werden. (Foto: Knut Berger/Archiv)

"Das wäre ein Fiasko", sagt der deutsche Sportler Carl Dohmann. Für ihn steht ein Lebenstraum auf dem Spiel.

Was tun, wenn keine Bundesliga-Spiele stattfinden? (flw)

+++ Das Branchentreffen mit rund 6000 Ausstellern soll jetzt vom 13. bis 17. Juli stattfinden. +++

Jetzt wurde die Bischofsweihe am 21. März doch abgesagt.

Postponement Jetzt verkündet der Pay-TV-Sender Sky eine sensationelle Neuigkeit.

of events

Die Queen wird zunächst keine königlichen Termine wahrnehmen.

Ausnahmesituation in Fußball-Deutschland: die Bundesliga hat wegen des

Coronavirus Zwangspause. Im Fußball-Podcast "Eine Halbzeit mit" drehen

Sky-Kommentator Wolff Fuss und RND-Sportchef Heiko Ostendorp zumindest die verbalen Kugeln weiter.

Was wird als nächstes abgesagt?

Angesichts der Corona-Pandemie hat der Herdecker Kanu-Club die 46. Herdecker

Kanu-Regatta, die vom 29. bis 31. Mai stattfinden sollte, abgesagt.

Wir aktualisieren diesen Text fortlaufend. 
Bürger können unter der Rufnummer 0201/123 8888 Fragen zum Coronavirus stellen. Die Hotline ist täglich von 8 bis $18 \mathrm{Uhr}$ freigeschaltet.

UPDATE Derzeit erreichen sowohl uns als auch den Kreis Mettmann eine Vielzahl von Fragen bezüglich des \#Coronavirus. Dazu teilen wir eine aktuelle Meldung des Kreis Mettmann. Dazu unser Hinweis: Sollten Sie auch konkrete Fragen haben, stellen Sie diese bitte auf der Facebook-Seite des Kreises - dort laufen alle Informationen zusammen und dort liegen die auch Zuständigkeiten. Infos gibt es auch über die Service-Hotline des Kreises Mettmann, welches werktags von 8 bis 20 Uhr unter 02104993535 geschaltet ist. Direkten Zugriff auf die aktuellen Meldungen aus dem Krisenstab im \#KreisMettmann gibt es auch auf dem Presseportal des Kreises Mettmann: https://t1p.de/5ndt:=:https://www.kreis-mettmann.de/Kreis-Politik/PresseKommunikation/Pressemitteilungen/Archiv-Pressemittelungen-Kreis-Mettmann oder direkt auf der hierfür speziell eingerichteten und laufend aktualisierten Internet-Seite unter:...

Jetzt am Dolomiten-Telefon unter der Nummer 0471/925402.

UPDATE Auch das UPDATE vom Kreis Mettmann am heutigen Donnerstag, zur aktuellen Situation im Kreisgebiet, teilen wir an dieser Stelle natürlich wieder auf eigener Seite. Direkten Zugriff auf die aktuellen Meldungen aus dem Krisenstab im \#KreisMettmann finden Interessierte auch jederzeit aktuell auf der Facebook-Seite von Kreis Mettmann, als Pressemitteilung im Internet unter:

https://t1p.de/5ndt:=:https://www.sonderlage-kreis-mettmann.de/ oder direkt auf der hierfür speziell eingerichteten und laufend aktualisierten Internet-Seite unter: http://ow.ly/Gri150yxne9.:=:https://www.sonderlage-kreis-mettmann.de/ Dazu hier wiederholt der für uns wichtige Hinweis Wir teilen die nachfolgenden Informationen nur Sollten Sie konkrete Fragen und Anmerkungen zur aktuellen Mitteilung, bzw. zum Thema \#Coronavirus im \#KreisMettmann allgemein haben, stellen Sie diese bitte auf der Facebook-Seite des Kreis Mettmann unmittelbar ein dort laufen alle Informationen zusammen und dort liegen auch die entsprechenden Zuständigkeiten und Kompetenzen vor. Bitte bleiben Sie gesund! Ihre \#PolizeiME

UPDATE Auch das heutige UPDATE vom Kreis Mettmann, bezüglich der aktuellen Entwicklungen zum \#Coronavirus im Kreisgebiet, teilen wir heute natürlich wieder an dieser Stelle auf eigener Seite. Direkten Zugriff auf die aktuellen Meldungen aus dem Krisenstab im \#KreisMettmann finden Interessierte auch jederzeit aktuell auf der Facebook-Seite von Kreis Mettmann, als Pressemitteilung im Internet unter: https://t1p.de/5ndt:=:https://www.sonderlage-kreis-mettmann.de/ oder direkt auf der hierfür speziell eingerichteten und laufend aktualisierten Internet-Seite unter: http://ow.ly/Gri150yxne9.:=:https://www.sonderlage-kreis-mettmann.de/ Dazu noch hier ein für uns sehr wichtiger Hinweis Wir teilen die nachfolgenden Informationen nur Sollten Sie konkrete Fragen dazu, bzw. zum Thema \#Coronavirus im \#KreisMettmann allgemein haben, stellen Sie diese bitte auf der Facebook-Seite des Kreis Mettmann unmittelbar - dort laufen alle Informationen zusammen und dort liegen auch...

„Bist du zu oft gegen den Pfosten gelaufen?“ 
UPDATE Auch das UPDATE vom Kreis Mettmann am heutigen Dienstag, zur aktuellen Situation im Kreisgebiet, teilen wir an dieser Stelle natürlich wieder auf eigener Seite. Direkten Zugriff auf die aktuellen Meldungen aus dem Krisenstab im \#KreisMettmann finden Interessierte auch jederzeit aktuell auf der Facebook-Seite von Kreis Mettmann, als Pressemitteilung im Internet unter:

https://t1p.de/5ndt:=:https://www.sonderlage-kreis-mettmann.de/ oder direkt auf der hierfür speziell eingerichteten und laufend aktualisierten Internet-Seite unter: http://ow.ly/Gri150yxne9.:=:https://www.sonderlage-kreis-mettmann.de/ Dazu hier erneut der für uns sehr wichtige Hinweis Wir teilen die nachfolgenden Informationen nur Sollten Sie konkrete Fragen und Anmerkungen zur aktuellen Mitteilung, bzw. zum Thema \#Coronavirus im \#KreisMettmann allgemein haben, stellen Sie diese bitte auf der Facebook-Seite des Kreis Mettmann unmittelbar ein dort laufen alle Informationen zusammen und dort liegen auch die entsprechenden Zuständigkeiten und Kompetenzen vor. Bitte bleiben Sie gesund! Ihre \#PolizeiME

UPDATE Auch das UPDATE vom Kreis Mettmann am heutigen Freitag, zur aktuellen Situation im Kreisgebiet, teilen wir an dieser Stelle natürlich wieder auf eigener Seite. Direkten Zugriff auf die aktuellen Meldungen aus dem Krisenstab im \#KreisMettmann finden Interessierte auch jederzeit aktuell auf der Facebook-Seite von Kreis Mettmann, als Pressemitteilung im Internet unter: https://t1p.de/5ndt:=:https://www.sonderlage-kreis-mettmann.de/ oder direkt auf der hierfür speziell eingerichteten und laufend aktualisierten Internet-Seite unter:

Practical local information http://ow.ly/Gri150yxne9.:=:https://www.sonderlage-kreis-mettmann.de/ Dazu hier wiederholt der für uns wichtige Hinweis Wir teilen die nachfolgenden Informationen nur Sollten Sie konkrete Fragen und Anmerkungen zur aktuellen Mitteilung, bzw. zum Thema \#Coronavirus im \#KreisMettmann allgemein haben, stellen Sie diese bitte auf der Facebook-Seite des Kreis Mettmann unmittelbar ein dort laufen alle Informationen zusammen und dort liegen auch die entsprechenden Zuständigkeiten und Kompetenzen vor. Bitte bleiben Sie gesund! Ihre \#PolizeiME

Aktuelle Informationen zum Coronavirus, Stand 16.03., 17:46 Uhr Einreichung von Wahlvorschlägen für die Kommunalwahlen und die Integrationsratswahl 2020/Auswirkungen des Corona-Virus Aufgrund der aktuellen Sachlage zum Corona-Virus wird für den Bereich der Wahlvorschlagsprüfung für die Kommunalwahlen und die Integrationsratswahlen folgendes festgelegt: Es finden ab sofort keine Termine mit Parteien/Wählergruppen oder Einzelbewerber*innen vor Ort in der Stabsstelle für Wahlen und Informationslogistik, Außenstelle: Wahlamt, In den Haesen 84, 47198 Duisburg statt. Alle Unterlagen können in den Briefkästen der Stabsstelle für Wahlen und Informationslogistik In den Haesen 84, 47198 Duisburg oder Bismarckplatz 1, 47198 Duisburg hinterlegt werden. Die Quittungen für diese Unterlagen können per Mail ausgestellt werden. Dies gilt insbesondere auch für die Sammlungen der Unterstützungsunterschriften. Alle erforderlichen Informationen und Formulare (außer Formblätter für...

"Meine Oma ist allein": Enkel bittet Twitter-User um Briefe für einsame Großmutter

Amelie ist 24, Studentin und querschnittsgelähmt - für sie ist das Coronavirus lebensgefährlich. Sie gehört zur Risikogruppe. Ihre Bitte: Denkt nicht nur an euch! Denkt an eure Mitmenschen! \#miteinanderstark https://www.mdr.de/miteinander-stark-in-corona-zeiten/index.html

Familien-Gym. Tochter Hailey hatte richtig Spaß, Papa und Eintracht Frankfurt-Spieler Timothy Chandler bei seinem "Home Office" zu unterstützen. \#WirBleibenZuhause 
Helden gesucht! Ihr seid Verkäufer, Polizistin, Busfahrer, Krankenschwester, o.ä. und macht euren Job trotz Corona-Krise? Wir wollen wissen, wie IHR das managt, wie es bei EUCH zuhause und im Job zugeht. Schreibt uns unter diesem Post. Wir wollen im Frühstücksfernsehen mit einigen von euch skypen oder per FaceTime sprechen. \#alltagshelden

Solidarity \& Seit Tagen in Quarantäne, da ist Kreativität gefragt!

Tolle Beispiele, wie man jetzt helfen kann.

Noch Fragen...? \#STAYATHOME! Das ist englisch und bedeutet soviel wie \#BLEIBTZUHAUSE. Passt auf euch auf. :-* \#WIRBLEIBENZUHAUSE \#KAS \#klinikamsüdring SAT.1 filmpool

Das sind doch mal Tipps, die man wirklich gut brauchen kann!

Plötzlich wieder Kinderzimmer! Was macht das mit der Beziehung von Mutter und erwachsener Tochter?

Bei "Grünberg \& Kuhnt - Kommissare ermitteln" sind nicht nur Lara Grünberg und Bernie Kuhnt unterwegs. Sie haben auch ein fabelhaftes Team um sich herum: Sina Peters \& Thomas Bossmann und Vicky Sommer \& Christian König! — "Grünberg \& Kuhnt - Kommissare ermitteln" | ab MO um 18:30 Uhr in SAT.1 \#grünbergundkuhnt \#Kommissareermitteln \#filmpool \#SAT1 filmpool \#bleibtgesund

Rezeptur der WHO: Fehlt Desinfektionsmittel, können Apotheken dies sehr leicht selbst herstellen!

Teilweise werden die Waren nur noch vor der Haustür abgestellt.

In den Niederlanden wird nicht nur Toilettenpapier gehamstert - sondern auch Haschisch.

Betreiber von Fakeshops werben für Hygieneartikel und andere Waren zu besonders günstigen Preisen.

Statt mit feinem Garn und edlen Stoffen hantiert sie jetzt mit Nudeln, Mehl und Toilettenpapier.

"Nudeln und Klopapier": Alles über den neuen Wohnzimmer-Corona-Channel

Unsicherheit wegen dem Coronavirus: Regale mit Reinigungstüchern oder

Desinfektionsmitteln sind leer geräumt, das Büchsenbrot feiert Comeback. "Den

Handel freut's" - so der Vize-Geschäftsführer des Handelsverbandes

Berlin-Brandenburg.

Mehr als sieben Tonnen Lebensmittel lagern bei nur einem Caterer im Kühlhaus!

Wegen Corona wurde das Essen abbestellt. Im Müll landet es aber nicht. 
Supplies \& shortages
Was war los in Mannheim, Heidelberg und im Rhein-Neckar-Kreis (außer \#Corona)? Eine kleine Auswahl aus unseren Presseberichten vom 25. März 2020 haben wir wie gewohnt zusammengestellt. \#Mannheim-Innenstadt: Bei \#Einbruch in Schnellrestaurant Bargeld erbeutet - \#Zeugengesucht https://www.presseportal.de/blaulicht/pm/14915/4556465 \#Mannheim-\#Herzogenried: \#Feuer gerät außer Kontrolle - Holzunterstände und unbewohnte Stallungen abgebrannt - 83-Jähriger leicht verletzt - \#Sachschaden 15.000 Euro \#Eberbach: Bei \#Streit \#Schreckschusswaffe gezogen und Kontrahenten bedroht - alkoholisierter 59-jähriger Mann festgenommen https://www.presseportal.de/blaulicht/pm/14915/4556471 \#Weinheim/: Versuchter \#Einbruch in Markthaus - \#Zeugengesucht https://www.presseportal.de/blaulicht/pm/14915/4556466 \#Schriesheim: \#Einbruch in Vereinsheim des Sportanglervereins - \#Zeugengesucht https://www.presseportal.de/blaulicht/pm/14915/4556467 Weitere Meldungen findet Ihr wie immer hier in unserem...

Wegen Corona-Krise: Schiesspflicht 2020 wird sistiert https://bit.ly/2xfMeDS:=:https://www.polizei-schweiz.ch/wegen-corona-kriseschiesspflicht-2020-wird-sistiert/_ _ https://klickehier.com/nichts_verpassen

Die Lufthansa streicht ihre Flüge von und nach China.

Über 100 ausgeflogene Passagiere haben ihre Quarantänestation in Deutschland erreicht.

Urlauber sitzen in Marokko fest. Das nordafrikanische Land und beliebte Urlaubsziel streicht wegen des Coronavirus alle Flugverbindungen nach Deutschland. (cose)

New York City ist dieser Tage wie in Watte verpackt. Selbst am sonst so belebten Times Square ist kaum noch etwas los. Unser Korrespondent berichtet:

An der Brenner-Grenze wurde laut Sicherheitskreisen ein Zug mit zwei

Travel and international Coronavirus-Verdachtsfällen an Bord gestoppt - Kurz darauf wurde der Zugverkehr zwischen Österreich und Italien eingestellt. developments

Uber 1000 Neuinfektionen seit gesten. 85 Tote.

British Airways fliegt wegen des Coronavirus nicht mehr von oder nach China. Bei der Lufthansa finden Flüge wie geplant statt.

Vor allem in New York, Kalifornien und Washington ist die Lage außer Kontrolle.

Schon mehr als 720 Todesopfer und Zehntausende Infizierte:

Tausende sitzen wegen des Coronavirus' auf einem Kreuzfahrtschiff vor Kalifornien fest. Ein ehemaliger Passagier starb an Covid-19. 


\section{Additional regression models}

Table A6: Information exposure and COVID-19 outcomes, disaggregated exposure to different information sources.

\begin{tabular}{|c|c|c|c|c|}
\hline & \multicolumn{2}{|c|}{ Perceptions } & \multirow{2}{*}{$\begin{array}{c}\text { Attitudes } \\
\text { Trust in actors }\end{array}$} & \multirow{2}{*}{$\begin{array}{c}\text { Behaviours } \\
\text { Measures taken }\end{array}$} \\
\hline & Risk of infection & Effectiv. of measures & & \\
\hline \multirow[t]{2}{*}{ Public broadcasting } & $3.79^{* *}$ & $6.57^{* * *}$ & $7.92^{* * *}$ & $5.08^{* * *}$ \\
\hline & $(1.22)$ & $(1.20)$ & $(1.13)$ & $(1.14)$ \\
\hline \multirow{2}{*}{ Commercial broadcasting } & 0.91 & $2.57^{* * *}$ & $1.76^{* *}$ & $1.80^{* *}$ \\
\hline & $(0.64)$ & $(0.63)$ & $(0.60)$ & $(0.60)$ \\
\hline \multirow[t]{2}{*}{ Newspapers } & $1.56^{*}$ & 0.43 & 0.70 & 0.19 \\
\hline & $(0.69)$ & $(0.68)$ & $(0.64)$ & $(0.64)$ \\
\hline \multirow[t]{2}{*}{ Social media } & 0.22 & $1.73^{*}$ & -0.31 & $1.60^{*}$ \\
\hline & $(0.74)$ & $(0.73)$ & $(0.68)$ & $(0.68)$ \\
\hline \multirow{2}{*}{ Personal conversations } & $1.67^{* *}$ & $-1.27^{*}$ & 0.25 & $1.81^{* *}$ \\
\hline & $(0.63)$ & $(0.62)$ & $(0.58)$ & $(0.59)$ \\
\hline \multirow[t]{2}{*}{ Political ideology (left/right) } & -0.05 & -0.09 & $-0.54^{* *}$ & 0.04 \\
\hline & $(0.21)$ & $(0.20)$ & $(0.19)$ & $(0.19)$ \\
\hline \multirow[t]{2}{*}{ Political interest } & $0.84^{*}$ & 0.34 & 0.10 & $0.90^{*}$ \\
\hline & $(0.41)$ & $(0.40)$ & $(0.38)$ & $(0.38)$ \\
\hline \multirow[t]{2}{*}{ Satisfaction with democracy } & 0.22 & $0.63^{* * *}$ & $2.20^{* * *}$ & $0.48^{* * *}$ \\
\hline & $(0.16)$ & $(0.15)$ & $(0.14)$ & $(0.14)$ \\
\hline \multirow[t]{2}{*}{$\mathrm{CDU} / \mathrm{CSU}$} & -1.86 & 0.77 & $8.60^{* * *}$ & -1.07 \\
\hline & $(1.42)$ & $(1.40)$ & $(1.31)$ & $(1.32)$ \\
\hline \multirow[t]{2}{*}{ FDP } & -2.20 & -1.86 & $5.07^{* * *}$ & -1.43 \\
\hline & $(1.64)$ & $(1.62)$ & $(1.52)$ & $(1.53)$ \\
\hline \multirow[t]{2}{*}{ Grüne } & -0.82 & 0.28 & $5.94^{* * *}$ & -0.67 \\
\hline & $(1.52)$ & $(1.49)$ & $(1.40)$ & $(1.41)$ \\
\hline \multirow[t]{2}{*}{ Linke } & -3.33 & $-3.99^{*}$ & 2.76 & $-4.94^{* *}$ \\
\hline & $(1.74)$ & $(1.71)$ & $(1.61)$ & $(1.62)$ \\
\hline \multirow[t]{2}{*}{ SPD } & -2.23 & -1.23 & $7.46^{* * *}$ & $-3.59^{*}$ \\
\hline & $(1.61)$ & $(1.59)$ & $(1.49)$ & $(1.50)$ \\
\hline \multirow[t]{2}{*}{ Other party or don't know } & -1.21 & -2.32 & $3.96^{* *}$ & $-3.10^{*}$ \\
\hline & $(1.38)$ & $(1.36)$ & $(1.27)$ & $(1.28)$ \\
\hline \multirow[t]{2}{*}{ Household: 2 persons } & 1.14 & 1.63 & -1.12 & $2.23^{*}$ \\
\hline & $(1.02)$ & $(1.00)$ & $(0.94)$ & $(0.94)$ \\
\hline \multirow[t]{2}{*}{ Household: $3+$ persons } & $2.29^{*}$ & 1.96 & -1.67 & $4.94^{* * *}$ \\
\hline & $(1.06)$ & $(1.05)$ & $(0.98)$ & $(0.99)$ \\
\hline \multirow[t]{2}{*}{ Age } & $-0.29^{* * *}$ & -0.02 & $0.07^{* *}$ & -0.03 \\
\hline & $(0.03)$ & $(0.03)$ & $(0.02)$ & $(0.02)$ \\
\hline \multirow[t]{2}{*}{ Female } & -0.19 & $4.08^{* * *}$ & $2.13^{* * *}$ & $3.33^{* * *}$ \\
\hline & $(0.66)$ & $(0.65)$ & $(0.61)$ & $(0.62)$ \\
\hline \multirow[t]{2}{*}{ Medium education } & 1.63 & 1.17 & 0.10 & 1.53 \\
\hline & (1.09) & (1.08) & (1.01) & (1.02) \\
\hline \multirow[t]{2}{*}{ High education } & 1.90 & -0.71 & -1.65 & $3.19^{* *}$ \\
\hline & (1.08) & (1.07) & (1.00) & (1.01) \\
\hline $\mathrm{R}^{2}$ & 0.07 & 0.06 & 0.21 & 0.07 \\
\hline Adj. $R^{2}$ & 0.07 & 0.05 & 0.20 & 0.06 \\
\hline Num. obs. & 2943 & 2949 & 2940 & 2949 \\
\hline
\end{tabular}


Table A7: Information exposure and COVID-19 outcomes, disaggregated exposure to different information sources. Facebook use instead of all social media use.

\begin{tabular}{|c|c|c|c|c|}
\hline & \multicolumn{2}{|c|}{ Perceptions } & \multirow{2}{*}{$\begin{array}{c}\text { Attitudes } \\
\text { Trust in actors }\end{array}$} & \multirow{2}{*}{$\begin{array}{c}\text { Behaviours } \\
\text { Measures taken }\end{array}$} \\
\hline & Risk of infection & Effectiv. of measures & & \\
\hline \multirow[t]{2}{*}{ Public broadcasting } & $3.79^{* *}$ & $6.57^{* * *}$ & $8.05^{* * *}$ & $4.88^{* * *}$ \\
\hline & $(1.22)$ & $(1.20)$ & $(1.13)$ & $(1.13)$ \\
\hline \multirow[t]{2}{*}{ Commercial broadcasting } & 0.89 & $2.39^{* * *}$ & $1.63^{* *}$ & $1.87^{* *}$ \\
\hline & $(0.65)$ & $(0.64)$ & $(0.60)$ & $(0.60)$ \\
\hline \multirow[t]{2}{*}{ Newspapers } & $1.55^{*}$ & 0.39 & 0.68 & 0.19 \\
\hline & $(0.69)$ & $(0.68)$ & $(0.64)$ & $(0.64)$ \\
\hline \multirow[t]{2}{*}{ Facebook } & 0.39 & $3.08^{* * *}$ & 0.72 & 0.86 \\
\hline & $(0.84)$ & $(0.82)$ & $(0.77)$ & $(0.78)$ \\
\hline \multirow[t]{2}{*}{ Personal conversations } & $1.67^{* *}$ & $-1.32^{*}$ & 0.18 & $1.89^{* *}$ \\
\hline & $(0.63)$ & $(0.62)$ & $(0.58)$ & $(0.59)$ \\
\hline \multirow[t]{2}{*}{ Political ideology (left/right) } & -0.05 & -0.11 & $-0.55^{* *}$ & 0.04 \\
\hline & $(0.21)$ & $(0.20)$ & $(0.19)$ & $(0.19)$ \\
\hline \multirow[t]{2}{*}{ Political interest } & $0.85^{*}$ & 0.37 & 0.11 & $0.91^{*}$ \\
\hline & $(0.41)$ & $(0.40)$ & $(0.38)$ & $(0.38)$ \\
\hline \multirow[t]{2}{*}{ Satisfaction with democracy } & 0.22 & $0.65^{* * *}$ & $2.21^{* * *}$ & $0.47^{* *}$ \\
\hline & $(0.16)$ & $(0.15)$ & $(0.14)$ & $(0.15)$ \\
\hline \multirow[t]{2}{*}{$\mathrm{CDU} / \mathrm{CSU}$} & -1.87 & 0.74 & $8.64^{* * *}$ & -1.15 \\
\hline & $(1.42)$ & $(1.39)$ & $(1.31)$ & $(1.32)$ \\
\hline \multirow[t]{2}{*}{ FDP } & -2.20 & -1.87 & $5.10^{* * *}$ & -1.49 \\
\hline & $(1.64)$ & $(1.62)$ & $(1.52)$ & $(1.53)$ \\
\hline \multirow[t]{2}{*}{ Grüne } & -0.82 & 0.30 & $6.00^{* * *}$ & -0.75 \\
\hline & $(1.52)$ & $(1.49)$ & $(1.40)$ & $(1.41)$ \\
\hline \multirow[t]{2}{*}{ Linke } & -3.35 & $-4.11^{*}$ & 2.71 & $-4.93^{* *}$ \\
\hline & $(1.74)$ & $(1.71)$ & $(1.61)$ & $(1.62)$ \\
\hline \multirow[t]{2}{*}{ SPD } & -2.24 & -1.37 & $7.44^{* * *}$ & $-3.65^{*}$ \\
\hline & $(1.61)$ & $(1.59)$ & $(1.49)$ & $(1.50)$ \\
\hline \multirow[t]{2}{*}{ Other party or don't know } & -1.22 & -2.36 & $4.00^{* *}$ & $-3.19^{*}$ \\
\hline & $(1.38)$ & $(1.35)$ & $(1.27)$ & $(1.28)$ \\
\hline \multirow[t]{2}{*}{ Household: 2 persons } & 1.15 & 1.66 & -1.09 & $2.22^{*}$ \\
\hline & $(1.02)$ & $(1.00)$ & $(0.94)$ & $(0.95)$ \\
\hline \multirow[t]{2}{*}{ Household: $3+$ persons } & $2.28^{*}$ & 1.94 & -1.67 & $4.94^{* * *}$ \\
\hline & $(1.06)$ & $(1.05)$ & $(0.98)$ & $(0.99)$ \\
\hline \multirow[t]{2}{*}{ Age } & $-0.29^{* * *}$ & -0.02 & $0.08^{* *}$ & -0.04 \\
\hline & $(0.03)$ & $(0.03)$ & $(0.02)$ & $(0.02)$ \\
\hline \multirow[t]{2}{*}{ Female } & -0.20 & $4.00^{* * *}$ & $2.06^{* * *}$ & $3.37^{* * *}$ \\
\hline & $(0.66)$ & $(0.65)$ & $(0.61)$ & $(0.62)$ \\
\hline \multirow[t]{2}{*}{ Medium education } & 1.62 & 1.14 & 0.08 & 1.53 \\
\hline & $(1.09)$ & $(1.07)$ & $(1.01)$ & $(1.02)$ \\
\hline \multirow[t]{2}{*}{ High education } & 1.90 & -0.72 & -1.64 & $3.17^{* *}$ \\
\hline & $(1.08)$ & $(1.07)$ & $(1.00)$ & $(1.01)$ \\
\hline $\mathrm{R}^{2}$ & 0.07 & 0.06 & 0.21 & 0.07 \\
\hline Adj. $R^{2}$ & 0.07 & 0.06 & 0.20 & 0.06 \\
\hline Num. obs. & 2943 & 2949 & 2940 & 2949 \\
\hline
\end{tabular}




\section{References}

Destatis. 2018. "Ergebnisse des Mikrozensus 2017." https://www.destatis.de/DE/ZahlenFakten/ GesellschaftStaat/Bevoelkerung/Mikrozensus.html.

GESIS. 2020a. "GESIS Panel Extended Edition." GESIS Data Archive, Cologne. ZA5664 Data file Version 37.0.0, https://doi.org/10.4232/1.13572.

- 2020b. "GESIS Panel Standard Edition." GESIS Data Archive, Cologne. ZA5664 Data file Version 37.0.0, https://doi.org/10.4232/1.13573.

GESIS Panel Team. 2020. "GESIS Panel Special Survey on the Coronavirus SARS-CoV-2 Outbreak in Germany." GESIS Data Archive, Cologne. ZA5667 Data file Version 1.1.0, https://doi.org/10.4232/1.13520. 